\title{
Kıbrıs'ta Kurulmak İstenen Yeni Sistemde ‘Geçici Dönem' ile İlgili Düzenlemeler ve Özellikleri
}

\author{
Regulations Concerning the 'Temporary Period' in The \\ New System Sought to be Established in Cyprus and \\ Its Properties
}

\author{
Soyalp Tamçelik*
}

\begin{abstract}
Özet
Bu araştırmada, Kıbrı's'ta kurulmak istenen yeni sistemde 'Geçici Dönem' ile ilgili düzenlemeler ve özellikleri ele alınmıştır. Buradan hareketle araştırmanin temel amaci, Kıbris'ta taraflar arasinda cereyan eden görüşmelerde federal devlet kurulmazdan önce yapılması gerekli düzenlemelerin ve bunları gerçekleştirmesi beklenen kurumların nasıl yapılandırılacağı incelenmiştir. Geçici dönem, adında da anlaşılacağı üzere belli bir dönemi ifade eden ve Kıbrı'ta kurulması düşünülen yapının oluşumuna kadar sürmesi düşünülen dönemdir. O yüzden bu döneme, intikal dönemi' de demek mümkündür. Aslinda bu döneme karşı ileri sürülebilecek en tutarl formül, 'eşitlik temeline dayalı geşici ortak yönetim'formülü gibi görünmektedir. Özellikle toprak ve anayasal konularda uzlaşma için gerekli güven unsurunun sağlanması ve kurulacak federal devletin fonksiyonel özelliklerinin gerçek bir temele dayanıp dayanmadığını göstermesi açısından önemli olan formül, şimdilik en gerçekçi yöntem olarak ortada durmaktadir. Geçici dönemde yapılacak düzenlemeler ise Federal Anayasa ve Seçim Kanunu'nun hazırlanması, federal bürokrasinin tesisi, emlâk taleplerinin çözümlenmesi, ekonomik gelişme ve koruyucu hükü̈mlerin tespiti, toprak ayarlamaları ile ilgili düzenlemeler ve faaliyet programını hazıllamakla görevlendirilmiş bulunan iki toplumdan oluşan Komiteler tarafindan hayata geçirileceklerdir. Federal Cumhuriyet in kuruluşundan önce, birtakım 'Geçici Düzenlemelerin' yürürlüğe girmesini müteakip, ortaya yeni bir ortaklık devleti çıkacaktır. Bu ortaklık, anayasal açıdan iki toplumlu ve toprak açısından da iki kesimli bir federasyon çerçevesinde düzenlenen yeni bir devlet sistemi şeklinde kendini gösterecektir. Bu gerçekten hareketle araştırma, iki ana bölümden oluşmaktadır. Birinci bölümde Gali Fikirler Dizisi'ne göre Geçici Dönem ile ilgili düzenlemeler ve yapılacak diğer çalışmalara değinilmiştir. İkinci ve son bölümde ise Annan Planı'na göre Geçici Dönem ile ilgili düzenlemeler incelenmiştir.
\end{abstract}

Anahtar Kelimeler: Kibrıs, Gali Plânı, Annan Plânı, Federasyon, Geçici Düzenlemeler.

\section{Abstract}

In this research, regulations concerning the temporary period' in the new system sought to be established in Cyprus and its properties have been addressed. From this point of view, as the main purpose of this research, the regulations required during the talks taking place between the parties in Cyprus before a federal state is established and how the institutions expected to fulfill these will be structured have been observed. As could be understood from its name, temporary period reflects a certain period and is the period assumed to continue in Cyprus until the formation envisioned to be established there is achieved. Therefore, it is also possible to call this period a 'transition period'. Actually, the most consistent for-

Doç. Dr., Gazi Üniversitesi, İ̈BF, Uluslararası İlişkiler Bölümü, E-mail: soyalp@hotmail.com 
mula that could be brought forward towards this period seems to be the formula of temporary joint administration based on the principle of equality'. This formula, which is important for providing the necessary element of trust for negotiation particularly on issues of territory and constitution and also for displaying whether or not the functional properties of the federal state to be established is based upon a true foundation, appears for now as the most realistic method. On the other hand, the regulations to be made during the temporary period will come into effect with the preparation of the Federal Constitution and the Electoral Law, installing federal bureaucracy, analyzing property claims, determining economic development and protective provisions, regulations regarding territorial adjustments and through Committees, formed by the two communities, in charge of preparing the activity programme. Before a Federal Republic is established, a new state of partnership will emerge after the 'Temporary Regulations' enter into force. This partnership will reveal itself as a new state system organized within a framework of a federation that consists of two communities from a constitutional aspect and of two regions from a territorial aspect. Based on this fact, this research consists of two main sections. In the first section, regulations regarding the Temporary Period and other works to be conducted based on the Ghali Set of Ideas have been addressed. In the second and final section, regulations concerning the Temporary Period have been observed based on the Annan Plan.

Keywords: Cyprus, Ghali Plan, Annan Plan, Federation, Transitional Arrangements.

\section{Giriş}

Kıbrıs meselesinin bugün itibarıyla geldiği noktada barış, adalet ve insan hakları bakımından pek de övünülecek bir düzeye ulaştığı söylenemez. Aslında Kıbrıs'taki insanların barış talebi, her yerde olduğu gibi daha çok sahip oldukları maddî değerleri tehlikeye atmamak ya da güvence altına almak gereksiniminden doğmuştur.

Bu yönü ile Kıbrıs'taki barış arayışı, pratikte çıkarların korunması için zorunlu olarak oluşturulan kuvvetler dengesinin bir tezahürü olarak görülmüştür. ${ }^{1}$ Hâl böyle olunca Kıbrıs'ta oluşan kuvvetler dengesi, kurulmak istenen yeni düzenle ilgili arayışların birbirlerini sınama ihtiyacının doğal bir sonucu olarak ortaya çıkmıştır. Esasında bu sonuç, tarafları bir başka noktaya daha götürmüştür. Zira Kıbrıs meselesinde kişiler, olaylar ve kronolojiler hakkında enformasyon Akademik sıralamasına göre değil, toplumsal, siyasal, ekonomik, kültürel ve sosyal kurum ile süreçlerin analizine göre incelenmesini gerektirmiştir.

Bu yüzden Kıbrıs meselesi ile ilgili yapılan araştırmalarda daha çok kurumsal ve tasviri olarak devlet ve hukuk alanına önem verilmiştir. Fakat bulunacak yeni çözümde kurumların çalışma ilkesine ve mantığına hiç önem verilmemiştir. Ancak siyasal bir yapıyı, sadece resmî kurumlara ve kanunlara bakarak anlamak mümkün değildir. Resmî veya siyasal kurumların gerisindeki gayrı resmî kuvvetleri, kurumları, kuruluşları, dinamikleri ve bunların işleyişini, biriyle olan karşılıklı ilişkilerini tetkik etmeden, siyasal hayatın gerçek oluşumu hakkında gerçekçi yargılara ulaşmak güç, belki de imkânsız gibidir. Bundan ha-

1 Barış ve Garış olgusunun oluşturulması için bkz... Soyalp Tamçelik, "Kıbrıs Meselesinde Metodolojik Sorunlar ve Çözüm Önerileri”, Journal of World of Turks, II/2, (2010a), s. 127; Soyalp Tamçelik, Kıbrıs'taki Çatışmanın Hukukî Boyutu, IQ Yayınları, İstanbul, 2012e, s. 41. 
reketle Kıbrıs meselesinde bulunacak yeni çözümlerin kurumsal ve tasvirî olmaktan ziyade fonksiyonel ve davranış̧ı bir nitelik taşımasında büyük fayda vardır. ${ }^{2}$

Bütün bunlara rağmen Kıbrıs meselesi ile ilgili araştırmalarda daha çok siyasal hayata, anayasal kurumların özelliklerine, kamu ve siyasal alanı etkileyecek kuvvetlere ve dinamiklere önem verildiği görülmüştür. Bu özellikler çerçevesinde Kıbrıslı Türklerle Rumların, BM çözüm önerileri çerçevesinde takındıkları tutumları incelemek gerektirmiştir. Örneğin 1992'de Gali Fikirler Dizisi'nde ve 2002'de Annan Plânı çerçevesinde sunulan çözüm önerilerinde, tarafların algılamaları, itirazları, kabulleri ve buna dayalı analizleri gün yüzüne çıkartılabilecektir.

Özellikle 1992 yılında New York'ta yapılan toplumlararası görüşmelerde Kıbrıs'ta kurulacak düzenin yeni parametreleri belirlenmiştir. Buna göre Fikirler Dizisi'nin mimarı sayılan Butros Gali ve 'Birleşik Kıbrıs' yönetiminin başta gelen savunucusu ABD, uluslararası düzen ile Kıbrıs'taki ulusal üniteler arasında sıkı bir bağlantı kurmaya çalışmıştır. Böylece Kıbrıs'ta kurulacak yeni düzen, hem 1974'ten önce, hem de 1974'ten sonra var olan iki bağımsız düzeni birleştirecek bir nitelik taşımasına çalışılmıştır. ${ }^{3}$ Böylece iki taraf arasında, normatif bir düzen tesis edilmek istenmiştir.

2002-2004 yılları arasında yapılan görüşmelerde ise Annan Planı ortaya çıkmış ve bu plana göre iki etnisite, kurumlarıyla birlikte yeni kurulacak sisteme entegre edilmeye çalışılmış ve böylece toplumsal düzen AB sistemi içinde dengelenme gayretini girilmiştir.

$\mathrm{Bu}$ araştırmada uygulanan yöntem konusuna gelince, konu esas itibarıyla süreç analizine dair bir yöntem uygulanmıştır. Dolayısıyla geleneksel hadise naklinin yerine, daha çok analitik tarih ikame edilmeye çalışılmıştır. Bu yöntemle, Kıbrıs'ta kurulması düşünülen federal sistemden hemen önce ortaya çıkması beklenen sıkıntıların veya sorunların geçici düzenlemelerle nasıl çözümleneceği veya çözümlenmesinin mümkün olup olmadığı tartışılacaktır.

\section{Gali Fikirler Dizisi'ne Göre Geçici Dönem ile İlgili Düzenlemeler}

Geçici dönem, adında da anlaşılacağı üzere belli bir dönemi ifade eden ve Kıbrıs'ta kurulması düşünülen yapının oluşumuna kadar sürmesi düşünülen dönemdir. O yüzden bu döneme, 'intikal dönemi' de demek mümkündür.

Bu döneme karşı ileri sürülebilecek en tutarlı formül, Denktaş'ın çok önceleri ortaya attığı ve hâlâ geçerli olan "eşitlik temeline dayalı geçici ortaklık

2 Soyalp Tamçelik, Kıbrı 'taki Çatışmanın Hukukî Boyutu, IQ Yayınları, İstanbul, 2012e, s. 19.

3 Soyalp Tamçelik, "Rum-Yunan İttifakında Ortak Savunma Doktrini ve Özellikleri", Stratejik Araştırmalar Dergisi, VI/12, (2008a), s. 17-18.

4 Soyalp Tamçelik, Kıbrıs Meselesinin Çözüm Plânları (BM'nin 789 Sayılı Kararına Göre), Gazi Ü. SBE., Ankara, 2008b, (Yayımlanmamış Doktora Tezi), s. 982.

Akademik Bakış 191 Cilt 8 Sayı 15 Kış 2014 
yönetimince" $^{\prime 5}$ formülize edildiği görülmüştür. Ne var ki bu formülün, Kıbrıs'ta toprak ve anayasal konularda uzlaşılması yönünde gerekli güven unsurunu sağlayıp sağlamadığı veya kurulmak istenen federal devletin fonksiyonel özelliklerinin gerçek temellere dayanıp dayanmadığını test edecek herhangi bir inceleme yapılmamıştır.

Ancak BM Genel Sekreteri ile onun özel temsilcilerin aylarca perde arkasında süren temasları sonunda, ortaya çıkan uzlaşı belgesinin onaylanmasıyla birlikte geçici dönemin fiilî başlangıç tarihi olarak kabul edilebileceği açılanmıştır. Böylece taraflar, komisyon çalışmalarının tamamlamasından ve her iki tarafın onayından sonra Federal Kıbrıs Cumhuriyeti'nin 'Geçici Federal Hükümeti'nin' kurulmasından söz edebileceklerdir.

Esasında bu dönemle ilgili olarak 'Geçici Ortak Hükümet' ve 'komisyonlar' gibi iki önemli kurum ortaya çıkacaktır. Bununla birlikte Federal Cumhuriyet'in kurulmasından önce, birtakım özel programların ve önlemlerin hazırlanması amacıyla, 'Geçiş Dönem'8 ile ilgili düzenlemelerinin bir parçası olarak iki toplumlu bir komisyonun oluşturulması gündeme gelecektir. Adı geçen bu komisyona, özellikle Birleşmiş Milletler Kalkınma Programı'ndan (UNDP) destek vermesi de istenecektir.

Aslında bu komisyonun amacl, bütünlüklü ve yönlendirici ilkeler ışığı altında kurucu anlaşmaları hazırlamaktır. Ayrıca komisyon, mutabakatın sonuçlarına uygun olarak nihaî anlaşmaları hazırlamakla da görevlendirilmiştir. Bu komisyonun görevleri arasında, İngiliz üslerine sağlanacak ulaşım, iletişim kolaylıkları ve askerî tatbikat alanlarının saptanması, vatandaşlık ve Federal Kıbrıs Cumhuriyeti'nin kuruluşuna ilişkin malî ve ekonomik meseleler de vardır. ${ }^{9}$ Geçici Komite'nin görev süresi ise Kıbrıs Federal Devleti'nin ilânı ile sona erecektir. Bu süre içinde özel destekleme programları ile Türk-Rum ekonomilerinin denkleştirilmesi, yasaların uyumlaştırılması, dış politika faaliyetlerinin ortak yürütülmesi ve silahsızlanma programlarının başlatılması da vardır. ${ }^{10}$

Akademik

Fikirler Dizisi'nde de ifade edildiği gibi geçici dönem sırasında dışişleri, Kapsamlı Çerçeve Antlaşması'ndaki ilkelerle uyum içinde olacak ve her iki

5 Mümtaz Soysal, Aklını Kıbrıs la Bozmak, Bilge Yayınevi, İstanbul, 1995, s. 66.

6 İsmail Sabahattin, "Kıbrıs'ta Çözüm Önerileri ve Örnekleri”, Kıbrıs Üzerine Bildiriler, Kıbrıs Araştırma ve Yayın Merkezi (CYREP) Yayınları, Lefkoşa, 1998a, s. 198.

7 Bu komisyonun bir benzeri 1960 yılında da kurulmuştur. Bu komisyonda Kıbrıs'ta çalışacak ve egemenliğin devrini kolaylaştıracak şekilde adadaki hükümet mekanizmasının yeniden teşkilâtlanmasını ve bununla ilgili programların hazırlanmasını sağlamıştır. Bunun için bkz... Ahmet Gazioğlu, Ingiliz Yönetiminde Kıbrıs Son İki Yil (1958-1960) ENOSiS Çemberinden Kıbris Cumhuriyeti'ne-3, Kıbrıs Araştırma ve Yayın Merkezi Yayınları, Ankara, 2000, s. 221.

8 "Set of Ideas on an Overall Framework Agreement on Cyprus", KKTC Dışişleri ve Savunma Bakanlığı Arşivi (KKTC DSBA), Konu: Gali Fikirler Dizisi, Tarih: 1992; "Set of Ideas on an Overall Framework Agreement on Cyprus”, KKTC Cumhurbaşkanlı̆̆ı Arşivi (KKTC CBA), Konu: Gali Fikirler Dizisi, Tarih: 1992.

9 Gazioğlu, a.g.e., s. 222

10 Sabahattin, a.g.m., 1998a, s. 198. 
toplum liderinin muvafakatiyle yürütülecektir. ${ }^{11}$ Özellikle uluslararası toplantılarda, ortak heyetlerin oluşturulmasına ilişkin düzenlemelerin yapılmasına özen gösterilecektir.

'Geçici Dönemde' Kıbrıs Türk ve Rum federe devletleri, Kapsamlı Çerçeve Anlaşması'na aykırı olmadan, iç hukuk kurallarında bağımsız ve egemen olması sağlanacaktır. Ancak geçici dönem sırasında, her bir tarafın güvenliğine ve içişlerine dair yönetim, Kapsamlı Çerçeve Antlaşması tarafından değişikliğe uğratılmadığı sürece devam edecektir. Ne var ki bu durum, Kıbrıs'ın bütününü ilgilendiren konularda söz konusu olamayacaktır. Örneğin uluslararası ticaret ve turizm gibi konularda, adadaki halkların 'ortak çıkarı' doğrultusunda davranılması gerektiğine dair anlayışın her zaman için korunması istenmiştir. ${ }^{12} \mathrm{Bu}$ amaçla Kıbrıs'taki her iki halktan, 'geçici işlemler' üzerinde mutabık kalacakları davranışlar beklenmektedir.

Hiç kuşku yok ki, Kıbrıslı Türklerle Rumların müştereken katılacağı bu komisyonun, anlaşmanın yürütülmesinde ve uygulanmasında büyük yardımı olacaktır. ${ }^{13}$ Zaten Kıbrıs gibi karmaşık meselelerde, geçiş dönemi ile ilgili bir dizi düzenlemeyi içeren protokollerin yapılması da bundandır. Aslında geçiş döneminin sağlıklı bir şekilde ürütülebilmesi veya yönetebilmek için 'Geçici Hükümetin' inşa edilmesi gerekeceği açıktır. Özellikle bu yöntem, her iki taraf için de en uygun yöntem olarak görülmüştür. Dolayısıyla Kıbrıs'ta kurulacak bir federasyonda Kapsamlı Çerçeve Antlaşması yürürlüğe girmeden önce yaşanması gereken en önemli husus, 'Geçiş Dönemi'ni ve bunu düzenleyen anlaşmaların yapılmasıdır. ${ }^{14}$ Bu şekilde 'Geçici Hükümet' 15 başarıyla kurulacak ve yönetim zafiyeti yaşanmayacak bir ortam oluşturulacaktır.

Bunun dışında geçici dönemin 18 ay gibi çok sınırlı bir süre içinde olması, ciddi sıkıntıları da beraberinde getirmesi beklenmektedir. Bu sıkıntıları ortadan kaldırabilmek için de bu tür anlaşmalarda tatbik edilen 'uygulama takvimi'16 gibi bir plânı hayata geçirmek gerekecektir. Aslında bir zorunluluk olan bu durum, Sırbistan-Karadağ Cumhuriyeti için 3 yıllık gibi bir geçiş dönemi

11 "Birleşmiş Milletler Çözüm Plânının Tam Metnini Açıklıyoruz", KKTC DSBA, Konu: Gali Fikirler Dizisi, Tarih: 1992, s. 6; Mehmet Ali Akpınar, "Birleşmiş Milletler Çözüm Plânının Tam Metnini Açılıyoruz", KKTC Başbakanlık Enformasyon Müdürlüğü Arşivi (KKTC BEMA), Konu: Gali Fikirler Dizisi, Tarih: 1992, s. 6.

12 "Birleşmiş Milletler Çözüm Plânının Tam Metnini Açılıyoruz", a.g.b., s. 6; Akpınar, a.g.m., s. 6.

13 Clemenet H. Dodd, The Cyprus Issue-A Current Perspective, 2. Edition, The Eothen Press, England, 1995, s. 10.

14 Şükrü S. Gürel, Tarihsel Boyut İçinde Türk-Yunan Illişkileri (1821-1993), Ümit Yayıncılık, Ankara, 1993, s. 113.

15 Haluk Ülman, "Her Çözüm, Çözüm Değildir”, Yeni Günaydın Gazetesi, 24 Aralık 1992, No:5332, s. 14; Orbay Deliceırmak (der.), Haklılık ve Kararllık (Tepkiler Demeti), Lefkoşa, 1993, s. 246; Zehra Yalçınkaya Cerrahoğlu, Birleşmiş Milletler Gözetiminde Kıbrıs Sorunu ile İlgili Olarak Yapılan Toplumlararası Görüşmeler (1968-1990), Kültür Bakanlı̆̆g Yayınları, İstanbul, 1998, s. 48.

16 Hüseyin Alkan, “İşte Annan'ın Çözüm Plânı”, Hürriyet Gazetesi, 10 Kasım 2000, No:98562, s. 26.

Akademik Bakış 193 Cilt 8 Sayı 15 Kış 2014 
öngörülürken, ${ }^{17}$ Kıbrıs gibi karmaşık bir meselede sadece 18 ay gibi bir sürenin ${ }^{18}$ öngörülmesi gerçekçi bir yaklaşımı değildir. ${ }^{19}$ Zira Annan Plânı'nda bile geçici dönem ile ilgili süre için 3 yıllık bir zaman dilimini ${ }^{20}$ ifade etmesi dikkatlerden kaçmamıştır.

\subsection{Gali Fikirler Dizisi'ne Göre Geçici Ortak Hükümet ve Çalışmaları}

Her şeyden önce Kıbrıs'ta olası bir anlaşmanın yürürlüğe girmesinden önce makul bir süre için ortak bir 'Geçici Hükümet' kurulması konjonktür gereği elzemdir. ${ }^{21}$ Aynı zamanda bu hükümetin görevi, esas ve daimi hükümetin kurulmasına imkân sağlayacağı da unutulmamalıdır.

Bunun için de Türk ve Rum liderleri, BM Genel Sekreteri'nin gözetiminde yapacakları bir anlaşmaya taraf olmalıdırlar. Ancak bu olduktan sonra kalıcı ve bütünlüklü bir çözümden söz edilebilir. Bu amaca binaen BM Genel Sekreteri Butros Gali, 1992 yılında 'Kıbrıs'ta Bütünlüklü Çerçeve Anlaşması'na dayalı yeni bir metin hazırlamıştır.

Aslında Kıbrıs meselesinin adil ve kalıcı bir çözüme kavuşturulması yönünde önemli bir adım olarak görülen 'Kıbrıs'ta Bütünlüklü Çerçeve Anlaşması', 22 tarafların uluslararası düzeyde yapacağı toplantılardan sonra her iki lider, anlaşmayı izleyen ilk 30 gün $^{23}$ içerisinde ayrı referandumlarla iki toplumun onayına sunacaktır.

Bir yönüyle Bütünlüklü Çerçeve Anlaşması, entegre bir bütün olup, her iki toplum tarafından ayrı referandumlarla onaylanıp, 'Geçici Düzenlemeler' ile ilgili hükümlerin yerine getirilmesinden sonra iki toplumun ilişkilerine hükmedecek, anayasal açıdan iki toplumlu, toprak yönünden ise iki kesimli federal bir temele dayalı yeni bir ortaklık ile sonuçlanacaktır. ${ }^{24}$ Aslında ifade edilen bu unsurların tamamı, nihâ̂ hedefler manzumesi içinde yer almaktadır. Bunu sağlayabilmek için de 'Geçici Hükümet'in yapacağı düzenlemelere ve alacağı bir dizi kararların başarıyla uygulanmasına bağlıdır. Örneğin BM çözüm plânında, anlaşmanın uygulanması için 18 aylık bir 'geçici dönem' öngörülürken, bu dönemde

'Geçici Hükümet'in alacağı kararlarda ilgili çalışma alanları, aşağıdaki gibi olması

17 Nur Batur, “Sırbistan - Karadağ Modeli Nedir?”, Hürriyet Gazetesi, 13 Nisan 2003, No:102336, s. 7.

18 Türk tarafı bu sürecin 5 yıl olmasını istemektedir. Belgeye göre iki taraf, gözden geçirme mekanizması çerçevesinde 5 yıl sonra gelinen noktayı değerlendirerek, işbirliğinin devamından yana olmaları durumunda yeni organlar oluşturabilecek ve ortaklık devletine yeni yetkiler verebilecektir. Bunun için bkz... "Belge Sunduk”, Kıbrıs Gazetesi, 12 Eylül 2002, No:6201, s. 18.

19 Tamçelik, a.g.t., 2008b, s. 983.

20 Hüseyin Alkan, "Planda Taraflar Neyi İstemiyor”, Hürriyet Gazetesi, 8 Aralık 2002, No:523361, s. 14.

21 Sabahattin İsmail, 150 Sorunda Kıbrıs Sorunu, Kastaş Yayınları, İstanbul, 1998b, s. 198.

22 “Birleşmiş Milletler Çözüm Plânının Tam Metnini Açıklıyoruz", a.g.b., s. 2; Akpınar, a.g.m., s. 2.

23 "Birleşmiş Milletler Çözüm Plânının Tam Metnini Açıklıyoruz", a.g.b., s. 2; Akpınar, a.g.m., s. 2.

24 "Birleşmiş Milletler Çözüm Plânının Tam Metnini Açıklıyoruz", a.g.b., s. 2. 
gerekecektir. Buna göre Geçici Hükümet'in şu çalışmalara ağırlık vermesi beklenmektedir.

1. Kıbrıslı Türklerle Rumlar arasında yürütülen görüşmelerin, meselesinin tüm yönlerini kapsayacak biçimde ve bölünmez bir bütün kavramı içerisinde sonuçlandırılmasına,

2. Üzerinde anlaşılan metinlerin her iki tarafta da ayrı ayrı yapılacak referandumlarla Kıbrıs Türk ve Rum yasama meclislerine getirilmesine,

3. Geçici hükümet kuruluncaya kadar bir denge sağlanması amacıyla, sonuçlanan güvenlik düzenlemeleri uyarınca, kuvvetlerin dengelenmesine ilişkin programın uygulanmasına,

4. Birbirinin yasal ve siyasal kimliklerini tanıdıklarına ilişkin karşılıklı olarak ve aynı zamanda yaptıkları federal deklarasyonlarla ilgili temel hükümler uyarınca, kurucu cumhuriyetlerin yeniden oluşturulmasına,

5. Karşılıklı mülk iddialarını görüşmek üzere görüşmelerin uygun bir zamanında oluşturulan geçici komite (ad-hoc) çalışmalarının değerlendirilmesine,

6. Federal Anayasa'nın ayrıntılı taslağının hazırlanması, üzerinde anlaşılan güvenlik düzenlemelerinin programlanması ve mutabık kalınan toprak düzenlemelerinin yeniden planlanması için ortak komitelerin oluşturulmasına. ${ }^{25}$

7. İki kurucu cumhuriyetin temsilcilerinin, Kıbrıs meselesine kapsamlı bir çözümü öngören anlaşmayı imzalamasına ve aynı zamanda 'Geçici Hükümet'in kurulmasina,

8. Federasyonun uluslararası forumlarda tanınması için 'Geçici Hükümet'in, uluslararası kuruluşlara bildirimde bulunmasına,

9. Güvenlik Konseyi'nin, 'Geçici Hükümet'le varılacak bir mutabakata göre BM Barış Gücü'ne, federasyonun ilk aşamalarında görev yapması için vereceği yetkinin belli bir süre için onaylanmasına,

10. Karşılıklı mülk iddialarını inceleyen iki toplumlu geçici komitenin, temel ilkeler üzerinde anlaşmaya varıldığı ve karşılıklı bireysel hak iddialarının ortadan kalktığı noktasında bunun, her iki tarafça da teyit edilmesine,

11. Federal Anayasa'nın teknik taslağının sonuçlandırılmasına ve Geçici Hükümet ile kurucu cumhuriyetlerin yasama meclislerince onaylanmasına,

12. Federal hükümetçe, federasyonun tanınması ve diplomatik ilişkiler kurulması için Bileşmiş Milletler ve diğer devlet temsilcilerine çağrı yapılmasına,

Akademik Bakış

195

Cilt 8 Sayı 15 Kış 2014

25 GKRY Hükümet Sözcüsü Vekili Spiros Arodis, teknik komiteler konusunda "siyasal bir çözüm bulunur ve teknik problemler kalirsa, Gunlar elbette ki uzmanlardan oluşacak komitelere havale edilecektir. Onun için bu tür komitelerin oluşturulmasını şimdiden ihtimal dışı etmek doğru değildir. Ancak şimdiye kadar komitelerin oluşturulması hakkında bizim tarafın fikri sorulmamıştır. Komiteler oluşturulması geçmişte de gündeme gelmiş, ancak o zaman Kibris sorununun özünün bu komitelere havale edilmesinin düşünülmesi dolayısıyla Rum tarafı bunu reddetmiştir. Rum tarafı, siyasî problemlerin, siyasî düzeyde çözümlenmesinden ve sadece teknik problemlerin komitelere havale edilmesinden yanadır" görüşünü savunmuştur. Bunun için bkz... "Amerikalıların Plânı", Fileleftheros Gazetesi, 22 Şubat 1995, No:4407, s. 1; "Kıbrıs Rum Basını Özetleri", Türk Ajansı Kıbrıs Arşivi (TAKA), 22 Şubat 1995, s. 1. 
13. Üzerinde anlaşılan güvenlik düzenlemelerinin tamamlanmasına.

14. Toprak konusunda üzerinde anlaşmaya varılan düzenlemelerin tamamlanmasina,

15. BM Barış Gücü'nün, yani UNFICYP'in, sonunda lağvedilmek üzere bir 'gözlemci güce' dönüştürülmesine dikkat edilmesi gerekecektir. ${ }^{26}$

Ayrıca belirtilen 'Temel Ilkeler' çerçevesinde, Kıbrıs Türk ve Rum toplum liderlerinin 'Geçici Ortak Hükümet' içinde ortaklaşa icra edecekleri eylemlerin de yürütülmesi istenmiştir. ${ }^{27}$ Bunun dışında Federal Kıbrıs Cumhuriyeti, müstakbel Anayasası konusunda ve iki millî toplum arasındaki mevcut çözümlenmemiş çeşitli sosyal ve insanî konularda bir sonuca varmak amacıyla, iki toplum liderinin ortaklaşa nezaret edeceği 'Ortak Sekretarya' nın ${ }^{28}$ kurulması da kararlaştırılmıştır. Bu sekretarya, yukarıda ifade edilen konularda ve iki toplum lideri arasında varılan anlaşmaların uygulanmasında da aracı rol üstlenecektir.

Her şeyden önce 'Geçici Hükümet'in, Kıbrıslı Rumların çok önem verdiği ve olmazsa olmaz dediği Türk askerinin çekilmesi veya kuvvet indirimi konularında da karar vermesi istenecektir. Bu nedenle Geçici Hükümet'in, 'geçici dönem' ile ilgili olarak yapacağı en önemli şeyler arasında bu da sayılabilecektir.

Aslında adada geçici federal hükümetin kurulduğu tarihte, Kuzey Kıbrıs'ta Kıbrıslı olmayan ve Kıbrıslı Türk Kuvvetleri ile Güney Kıbrıs'ta Kıbrıslı olmayan ve Kıbrıslı Rum Kuvvetleri arasında yeni bir dengenin kurulması sağlanması gerekecektir. Ancak 'Geçici Hükümet'in kurulmasından sonra Kıbrıslı olmayan kuvvetler üzerinde mutabık kalınacak bir takvim uyarınca, etkin ve yeterli garantileri sağlamak için gerekli olan düzeye çekilmesi de karara bağlanacaktır.

Bunun için de Kıbrıs Türk ve Rum kuvvetlerinin gücü, önceden üzerinde mutabık kalınan prensipler çerçevesinde azaltılması gerekecektir. Aslında Kıbrıs Türk halkının karşı karşıya bulunduğu güvenlik sorunları, göz ardı edilemeyecek kadar önemli konulardır. Zira Kıbrıslı Türkler, bu gibi girişimlerin hedefi

Akademik olduğunda, "sorumsuz unsurlar"29 deyimi ile karşı karşıya kalabileceklerdir. Bu nedenle güvenlik konusu, karşılıklı anlayış üzerine çözülmesi gereken konuların başında gelmektedir. ${ }^{30}$ Bunun için de Geçici Hükümet ile varılan görüş birliği uyarınca çalışma yapılması esas olacaktır. ${ }^{31}$

Aslında Kapsamlı Çerçeve Anlaşması ve ona bağlı Fikirler Dizisi'nin temel amacı, anlaşmaların öngördüğü anayasal kurumların geçici dönemde

26 Daha ayrıntılı bilgi için bkz... Tamçelik, a.g.t., 2008b, s. 984-985.

27 Necati Münir Ertekün, In Search of A Negotiated Cyprus Settlement, Nicosia, 1981, s. 273-274.

28 Cerrahoğlu, a.g.e., s. 46.

29 “Kıbrıs Türk Tarafının Entegre Bütünün Bir Parçası Olarak 'Kıbrıslı ve Kıbrıslı Olmayan Kuvvetler' Konusuna Yaklaşımı", KKTC CBA, Konu: Türk Önerileri, Tarih: 9 Ocak 1989.

30 Tamçelik, a.g.t., 2008b, s. 986.

31 "1990 Yılında Sunulan 27 Sayfalık Türk Önerileri", KKTC CBA, Dosya: Türk Önerileri, Tarih: 1990. 
oluşturulmasını sağlamaktır. Özellikle kurulacak ortak devlet kurumları, geçiş dönemi içinde ve süresince oluşturulacaktır. Bu kurumlar, bu süre sonunda Kapsamlı Çerçeve Anlaşması'nın bütünlüklü ve yönlendirici ilkelerinde açıklandığı gibi çalışmaya başlayacaklardır. ${ }^{32}$ Bu anlaşmanın yürürlüğe girmesinden sonra Kıbrıs'taki iki tarafın liderleri, 18 ay $^{33}$ boyunca Kıbrıs'ın ortak idarecileri olacaklardır. Kaldı ki ortak idareciler, belli bir süre zarfında kendilerinin atayacağı bir Bakanlar Kurulu'nun yardımcılığında, yürütmeden sorumlu olacaklardır.

Bunun dışında kalıcı ve sürdürülebilir bir anlaşmanın imzalanmasından sonra anayasal kuruluşların oluşturulmasına ve devlet çarkı çalışmaya başlanmasına kadarki sürede, ki bu süre federal devlette 18 aydır, her iki toplum da kendilerini ayrı ayrı yönetim hakkına ${ }^{34}$ sahip olacaktır.

Bir diğer önemli konu da geçici hükümetin kurulması ile ortaya çıkacak siyasî durumdur. Özellikle Kıbrıslı Rumlar, bu konu hakkında büyük sıkıntıya düştüklerinden kendi kamuoylarında çeşitli fikirler ileri sürerek soruna çözüm bulmaya çalışmışlardır. Örneğin Gali'nin hazırladığı plana göre geçici federal hükümet, 'yasal Kıbrıs Cumhuriyeti'nin yerini alacağını ve böyle bir gelişmenin 'Kıbrıs Cumhuriyeti' için büyük bir tehlike oluşturacağını düşünmektedirler. ${ }^{35}$ Böyle ' $K \imath$ brıs Cumhuriyeti'nin tanınmış bir devlet olmayacağını ve Türklerin de bundan fazlasıyla yararlanacağını öne sürmektedirler. ${ }^{36}$ Hatta Denktaş'ın rahatlıkla sorun yaratarak, bu devletten kolayca ayrılabileceğini de iddia etmektedirler. ${ }^{37}$ Kaldı ki bu çözüm şekli, istenilen sonucu vermediği takdirde geçici hükümetten sonra sistem dağılacağın138 ve Kıbrıs Cumhuriyeti'nin, Denktaş'ın "sözde devletinin"39 statüsüne düşeceğini belirtmektedirler. Bu yüzden Kıbrıs Cumhuriyeti'nin varlığı, Rum yönetimince gözbebeğ ${ }^{40}{ }^{2}$ gibi korunmaya çalışılmaktadır. Aksi takdirde Rumlara göre Federal Kıbrıs Cumhuriyeti'nin kurulmasıyla birlikte geçecek 18 ay içinde anayasal boşluk olacağından Kıbrıs Cumhuriyeti'nin, bugün olduğu gibi anayasal düzenini koruması mümkün olmayacağından çekinmektedirler. Bir

32 Tamçelik, a.g.t., 2008b, s. 986.

33 "İşte Belge”, Kıbrıs Gazetesi, 13 Kasım 2002, No:1028, s. 9.

34 Background on The Cyprus Problem, Directorate General of Press and Information, Ünal Ofset Matbaacılık, Ankara, 1991, s. 19.

35 “BM ve ABD Türklere Yüzde 29.5 Toprak Önerecek", Simerini Gazetesi, 17 Temmuz 1992, No:3251, S. 21; "Güvenlik Konseyi”, Simerini Gazetesi, 27 Ağustos 1992, No:2018, s. 1; "Rum Basın Bülteni”, Türk Ajansı Kıbrıs Arşivi, 27 Ağustos 1992, s. 1; “Belge Sunduk”, a.g.g., S. 1; “KKTC Meclisi'nin Son Kararı”, Kıbrıs Gazetesi, 2 Ağustos 1992, No:3819, s. 3.

36 Tamçelik, a.g.t., 2008b, s. 987

37 Orbay Deliceırmak, "Toprak Konusu ve Rum Tutarsızlıkları 1964-1996", KKTC CBA Yayınlanmamış Özel Rapor, Lefkoşa, 1997, s. 54

38 İsmail, a.g.e., 1998b, s. 242.

39 "Yorgo Vasiliu: İyi Bir Başlangıç", Hürriyet Gazetesi, 10 Aralık 1992, No:62235, s. 17.

40 “DiSì: Boşluklar Doldurulmalı", Agon Gazetesi, 18 Eylül 1992, No:987, s. 1-2; "Rum Basın Bülteni”, TAKA, 18 Eylül 1992, s. 1-2.

Akademik Bakış 197 Cilt 8 Sayı 15 Kış 2014 
başka deyişle geçiş dönemi, Kıbrıs Cumhuriyeti'ni tamamen bertaraf edebileceği endişesini taşımaktadırlar. ${ }^{41}$

Hâlbuki BM çözüm plânında geçici bir dönem öngörülürken, bu dönemle ilgili olarak daha önceleri Rum Cumhuriyeti'ne dönüşmüş olan sözde 'Kıbrıs Hükümeti'nin dağılmasından söz edilmemektedir. ${ }^{42} \mathrm{Ne}$ var ki Türk tarafı, anlaşmanın imzalanması ile birlikte yasadışı Kıbrıs Hükümeti'nin geçersiz kılarak ortak bir geçici hükümet kurulmasını istemektedir. Fakat çözüm plânında, bu talebin dikkate almadığı görülmüştür. Zaten Vasiliu, konuyla ilgili olarak verdiği bir cevapta, "Kıbrıs devletini dağıtılmasının söz konusu olamayacağının"43 anlaşıldığı söylenmiştir. Hatta Türk tarafının 'Geçici Hükümet' kurulması hakkındaki isteğinin, ${ }^{44}$ Birleşmiş Milletler'in temel görüşüne aykırı olduğu belirtilmiştir.

Görüleceği üzere Türk tarafı, çerçeve anlaşmasının imzalanmasından sonraki geçiş dönemi için ortak bir 'Geçici Hükümet' kurulmasını isterken, Rum tarafı kontrolü altında bulundurduğu 'Kıbrıs Devleti'ni ortadan kaldıracağı gerekçesi ile buna karşı çıkmaktadır. Bu yüzden Kıbrıslı Rumlar, "Ortak Geçici Hükümeti”45 gereksiz bir unsur olarak görmektedirler. Ne var ki Kıbrıslı Türkler, 'Kıbrıs Cumhuriyeti'ne yama olmamak için 'Ortak Geçici Hükümet' talebinden vazgeçmeyecekleri düşünülmektedir.

\subsection{Gali Fikirler Dizisi'ne Göre Geçici Dönemde Yapılacak Diğer Çalışmalar}

Kapsamlı Çerçeve Anlaşması'nın uygulanması için yapılacak geçici düzenlemeler, her iki toplumun kaygılarını giderici nitelikte olacağı görülmüştür. Kapsamlı Çerçeve Anlaşması'na göre ayrı ayrı yapılacak referandumlarla onaylanan yeni düzen, iki toplum arasında iyi niyet ve yakın ilişkileri geliştirmeye yönelik bir eylem plânı ${ }^{46}$ uygulamaya koyacak hüviyettedir. Aslında 'Geçici Düzenlemeler', Kıbrıs'ta kurulacak federal sistemin ilk uygulanma basamaklarını oluşturmaktadır. Bu yüzden öngörülen uygulama aşamaları ile tedbirleri, iki tarafın liderleri arasında görüşülüp, kapsamlı bir çözümün ana hatları şeklinde belirlenmesi gerekecektir. ${ }^{47}$ Bu yüzden Geçici Düzenlemeler, Fikirler Dizisi'nin sekizinci bölümde yer alması boşuna değildir. Burada yeni düzenin onaylanmasından sonra Fede-

Akademik ral Anayasa'nın hazırlanması ve yürürlüğe konulması dahil, Kapsamlı Çerçeve

Cilt 8 Sayı 15 Kış 2014

41 "Yeni Gali Plânı", Alithia Gazetesi, 22 Temmuz 1992, No:1202, s. 3; "Rum Basın Bülteni”, TAKA, 22 Temmuz 1992, s. 3.

42 "Birleşmiş Milletler Çözüm Plânının Tam Metnini Açıklıyoruz", a.g.b., s. 1; Akpınar, a.g.m., s. 1.

43 "Vasiliu'nun Demeci", Haravgi Gazetesi, 12 Kasım 1992, No:5211, s. 2-3; "Rum Basın Bülteni", TAKA, 12 Kasım 1992, s. 3.

44 "Egemenliğe Dayanmayan Eşitlik, Eşitlik Değildir; Egemenliğe Dayanmayan Hak, Hak Değildir", Yeni Demokrat Gazetesi, 11 Ocak 1998, No:203, s. 7.

45 İsmail, a.g.e., 1998b, s. 251.

46 Eylem plânı için bkz... “Güvenlik Konseyi Gali Raporu'nu Ele Alıyor”, KKTC BEMA, Dosya: Gali Fikirler Dizisi, Tarih: 10 Nisan 1992, s. 8; “Güvenlik Konseyi Gali Raporu'nu Ele Alıyor”, Kıbrıs Gazetesi, 10 Nisan 1992, No:652, s. 8.

47 Zaim M. Necatigil, The Cyprus Question and The Turkish Position in International Law, Revised 2. Edition, Biddles Ltd Guildford and King's Lynn, Oxford University Press, London, 1998, s. 396. 
Antlaşması'nın uygulanması için bazı geçici tedbirlerin alınması ve bu tedbirlerin ${ }^{48}$ tümünün 18 ay içinde uygulanması gerektiğinden söz edilmektedir.

Geçici dönmemde yapılacak çalışmaların neler olduğu üzerinde yapılmış herhangi bir çalışma olmadı̆̆ı için konunun sistematize edilmiş hali şu şekilde olabilir. Buna göre:

\subsubsection{Geçici Düzenlemelerin Esasları ve Takviminin Belirlenmesi}

Kıbrıs'ta Bütünlüklü Çerçeve Antlaşması'nın ayrı ayrı referandumlarla onaylanmasından hemen sonra Federal Anayasa'nın hükmü şahsiyetince hazırlanıp konan ve Bütünlüklü Çerçeve Antlaşması'nda da uygulanması için belirlenen Geçici Düzenlemeler hayata geçirilecektir. Ancak 'Geçiş Dönemi' ne ${ }^{49}$ ait bütün düzenlemeler, 18 aylık gibi bir periyotta tamamlanması kararlaştırılmıştır.

\subsection{2. Çeşitli Konularda İki Toplumlu Komitelerin Kurulması}

Bütünlüklü Çerçeve Antlaşması'na uygun olarak iki toplumlu komiteler ${ }^{50}$ kurulacaktır. Bu komiteler, Federal Anayasa'nın ${ }^{51}$ ve Seçim Kanunu'nun hazırlanmasını ve yürürlüğe konulmasını, federal devlet hizmetlerle ilgili kurumların oluşturulmasını, mülkiyetle ilgili isteklerin karşılanmasını, ekonomik kalkınma ve koruma tedbirlerinin alınmasını, Federal Cumhuriyetin kurulduğu andan itibaren etkilenmesi beklenen toprak düzenlemeleriyle ilgili anlaşmaları ve buna ekte sunulan eylem planlarının yürütülmesini sağlayacaklardır.

Bundan başka, Garanti ve İttifak Anlaşmalarına ek olmak kaydı ile üç garantör devletin ve iki toplumun temsilcilerinden oluşacak bir komite de kurulacaktır. BM de her bir komiteye ayrıca yardım edecektir.

\subsubsection{Sürecin Referandumla Belirlenmesi ve Belli Bir Takvime Bağlanması}

İki toplum liderinin ve BM temsilcisinin katılacağı bir komite oluşturulacaktır. Bu komite, Geçiş Dönemi'nin daha rahat geçirilebilmesi için düzenleme prosedürlerini hazırlayacak ve yapılması gerekenleri, etkin ve zamanında yapılmasını

48 Alınması gereken tedbirlerle ilgili ayrıntılı bilgi için bkz... "Set of Ideas on an Overall Framework Agreement on Cyprus", KKTC DSBA, a.g.b.; "Set of Ideas on an Overall Framework Agreement on Cyprus", KKTC CBA, a.g.b.

49 'Geçici Düzenlemeler' ile ilgili bilgi için bkz... "Birleşmiş Milletler Çözüm Plânının Tam Metnini Açıklıyoruz", a.g.b., s. 6; "Set of Ideas on an Overall Framework Agreement on Cyprus", KKTC $D S B A$, a.g.b., md. 93; "Set of Ideas on an Overall Framework Agreement on Cyprus", KKTC CBA, a.g.b., md. 93; Akpınar, a.g.m., s. 6; Birleşmiş Milletler Güvenlik Konseyi 'nin 789 (1992) Sayılı Kararının Işı̆̆ıda Kıbrıs Sorunu ve Türkiye, Siyasî ve Sosyal Araştırmaları Vakfı - SiSAV, İstanbul, 1993, s. 15; Deliceırmak, a.g.e., 1993, s. 94. Bu çalışma bundan sonra "BMGK 789/1992..." şeklinde kısaltılacaktır.

50 İki toplum arasında kurulacak komitelerin çalışma ilke ve esasları üzerine daha ayrıntılı bilgi için bkz... "Set of Ideas on an Overall Framework Agreement on Cyprus", KKTC DSBA, a.g.b., md. 94; "Birleşmiş Milletler Çözüm Plânının Tam Metnini Açıklıyoruz", a.g.b., s. 6; Akpınar, a.g.m., s. 6; BMGK 789/1992..., a.g.e., s. 15; Deliceırmak, a.g.e., 1993, s. 94.

51 Temel Anayasa, federe devletlerin anayasalarından üstündür. Bunun için bkz... Ertan Efegil, Temel Konular Işı̆̆ında Annan Belgesi'nin Analizi, Gündoğan Yayınları, Ankara, 2003, s. 41. 
sağlayacaktır. ${ }^{52}$ Bunun yanı sıra komite, Bütünlüklü Çerçeve Antlaşması'nı 30 gün içinde ayrı ayrı referandumlarla onaylanmasını organize edecek ve geçiş sürecine uygun bir zamanda BM'nin yardımı ve desteğiyle Federal Anayasa'nın ve resmî seçimlerin yapılmasını ayrı ayrı referandumlarla düzenleyecektir.

\subsubsection{Federe Türk ve Rum Devletlerinin, İç Hukuk Kurallarında Bağımsız ve Egemen Olması}

Geçiş süreci boyunca her bir tarafın iç işlerinde ve günlük yönetim düzenlemelerinde bir değişim olmayacaktır. Ancak bu düzenlemeler, Bütünlüklü Çerçeve Antlaşması'nın şartları ile değiştirilmediği müddetçe devam edebilecektir. Ayrıca Kıbrıs'ın bütününü etkileyen uluslararası ticaret ve turizm gibi konularda da aynı prensip uygulanacaktır. ${ }^{53} \mathrm{Bu}$ amaçla, her iki toplum tarafından geçici düzenlemelerin uygulanması kabul edilecektir.

\subsubsection{Geçici Dönemde Türklerle Rumların Müşterek Çalışma Alanları}

Geçiş döneminin süresi boyunca, dışişleri ile ilgili konular, ${ }^{54}$ Bütünlüklü Çerçeve Antlaşması ve iki toplum liderlerinin fikir birliğindeki prensiplere uygun olarak yürütüleceklerdir. Adı geçen düzenlemeler, özellikle uluslararası toplantılara katılacak delegasyon için de yapılacaklardır. ${ }^{55}$

\subsubsection{Uluslararası Anlaşmaların Gözden Geçirilmesi}

Her iki kesimde de yürürlükte olan hükümler, yönetmelikler, tüzükler, sözleşmeler ve kanunlar, ${ }^{56}$ Bütünlüklü Çerçeve Antlaşmasi'na uygun olduğu sürece yürürlükte kalacaklardır. Federal hükümet, uluslararası anlaşmalardan önce nasıl bir tutum takınacağı ile ilgili karar vermek için mevcut konuyu gözden geçirebilecektir. ${ }^{57}$

52 Referandum süreci için bkz... "Set of Ideas on an Overall Framework Agreement on Cyprus", KKTC DSBA, a.g.b., md. 95; "Birleşmiş Milletler Çözüm Plânının Tam Metnini Açıklıyoruz", a.g.b., s. 6; Akpınar, a.g.m., s. 6; BMGK 789/1992..., a.g.e., s. 16; Deliceırmak, a.g.e., 1993, s. 94.

53 İç hukuk kurallarının neler olacağına dair bilgi için bkz... "Set of Ideas on an Overall Framework Agreement on Cyprus", KKTC DSBA, a.g.b., md. 96; "Birleşmiş Milletler Çözüm Plânının Tam Metnini Açılılıoruz", a.g.b., s. 6; Akpınar, a.g.m., s. 6; BMGK 789/1992..., a.g.e., s. 16; Delicerrmak, a.g.e., 1993, s. 95.

Akademik

54 Dışişlerinin nasıl çalışacağına ilişkin bilgi için bkz... "Set of Ideas on an Overall Framework Agreement on Cyprus", KKTC DSBA, a.g.b., md. 97; "Birleşmiş Milletler Çözüm Plânının Tam Metnini Açılıyoruz”, a.g.b., s. 6; Akpınar, a.g.m., s. 6; BMGK 789/1992..., a.g.e., s. 16; Deliceırmak, a.g.e., 1993, s. 95; Soyalp Tamçelik, "Kıbrıs'ta Kurulması Düşünülen Federal Devlette Yargı Organları ve Temel Özellikleri”, Türkiye Günlüğü Dergisi, 96, (2009b), s. 197-223.

55 Soyalp Tamçelik, "Kıbrıs'ta Kurulması Düşünülen Federasyonun Yapısal Özellikleri”, Uluslararası Tarih ve Sosyal Araştırmalar Dergisi, I/2, (2009c), s. 211-223; Soyalp Tamçelik, "Kıbrıs'ta Kurulması Düşünülen Federal Sistemde Toplum (Cemaat) Meclisleri ve Özellikleri”, Doğuş Üniversitesi Dergisi, XI/2, (2010b), s. 269-285.

56 "Set of Ideas on an Overall Framework Agreement on Cyprus", KKTC DSBA, a.g.b., md. 98; "Birleşmiş Milletler Çözüm Plânının Tam Metnini Açılıyoruz", a.g.b., s. 6; Akpınar, a.g.m., s. 6; BMGK 789/1992..., a.g.e., s. 16; Deliceırmak, a.g.e., 1993, s. 96; Soyalp Tamçelik, "Kıbrıs'ta Kurulması Düşünülen Federal Devletin Yasama Organı ve Özellikleri", Yakın Doğu Üniversitesi Sosyal Bilimler Dergisi, II/1, (2009a), s. 20-50.

57 Federal hükümetin yetki ve görevleri için bkz... Tamçelik, a.g.m., 2009e, s. 55-84; Soyalp 


\subsubsection{Federe Hükümetlerin ve Seçim Yasasının Oluşturulması}

Her toplum, kendi Federe Devlet Anayasası ve Seçim Kanunu'nu, Federal Anayasa'ya ve Seçim Kanunu'na ${ }^{58}$ uygun olarak hazırlayacak ve kendi federe devlet yönetimini buna göre tanzim edecektir. Federal Devlet Anayasası'nın oluşturulması ve federe devlet yönetiminin yeni esaslara göre düzenlenmesi, Federal Cumhuriyetin kurulmasıyla eş zamanlı olacaktır. ${ }^{59}$

\subsubsection{Federal Anayasa'nın Yürürlüğe Girişi ve Cumhuriyet'in Illânı Tarihi}

Federal Anayasa'nın yürürlüğe giriş tarihi, Anayasa' da belirtilecek ve bir yönüyle belirlenen tarih, Federal Cumhuriyet'in kuruluş tarihi olacaktır. ${ }^{60}$

\subsubsection{Toplum Liderinin ve BM Güvenlik Konseyi'nin Kararlılık Teyidi}

Her iki toplum tarafından Bütünlüklü Çerçeve Antlaşması'nın ayrı ayrı referandumlarla onaylanmasından hemen sonra iki toplum lideri, BM Genel Sekreteri'ne iletmek üzere Bütünlüklü Çerçeve Antlaşması'ndan beklentilerini ifade eden bir mektup yazacaklardır. Genel Sekreter, gerek bu mektuba ve gerekse Güvenlik Konseyi'nin daha önce mutabakata vardığı Bütünlüklü Çerçeve Antlaşması'na bağlı kalacağını bir kez daha teyit edeceklerdir. ${ }^{61}$ Bunun dışında Güvenlik Konseyi de Bütünlüklü Çerçeve Antlaşması'nda tarif edildiği şekilde Federal bir Cumhuriyet'in kurulmasına ilişkin iki toplumun kararlılığını teyit edecektir.

Kaldı ki bu hususla ilgili düzenlemelerin, Fikirler Dizisi'nin 93.-101. maddeleri arasında yer aldığı görülürken, anlaşmanın genel ruhunda var olduğu düşünülen bir dizi düzenlemeyi de ilâve etmek gerekecektir. Buna göre:

\subsubsection{Tarihî ve Dinî Yerlerin Kullanılması}

Her iki federe devlet, geçiş dönemi süresince tarihî yerlerin ve dinî yerlerin korunmasında ${ }^{62}$ ve/veya kullanılmasında ortak hareket edecektir.

Tamçelik, "Kıbrıs'ta Kurulması Düşünülen Sistemde Cumhurbaşkanı ve Yardımcısının Görev ve Yetkileri", Akademik Araştırmalar Dergisi, XI/42, (2009d), s. 76-96.

58 Federal Anayasa ve Seçim Kanunu ile ilgili yapılması gerekenler için bkz... "Set of Ideas on an Overall Framework Agreement on Cyprus”, KKTC DSBA, a.g.b., md. 99; "Birleşmiş Milletler Çözüm Plânının Tam Metnini Açıklıyoruz”, a.g.b., s. 6; Akpınar, a.g.m., s. 6; BMGK 789/1992.... a.g.e., s. 16; Delicerırmak, a.g.e., 1993, s. 96.

59 Tamçelik, a.g.m., 2009e, s. 55-84; Tamçelik, a.g.m., 2010b, s. 269-285.

60 "Set of Ideas on an Overall Framework Agreement on Cyprus", KKTC DSBA, a.g.b., md. 100; "Birleşmiş Milletler Çözüm Plânının Tam Metnini Açıklıyoruz", a.g.b., s. 6; Akpınar, a.g.m., s. 6; BMGK 789/1992..., a.g.e., s. 16; Deliceırmak, a.g.e., 1993, s. 96.

61 "Set of Ideas on an Overall Framework Agreement on Cyprus", KKTC DSBA, a.g.b., md. 101; "Birleşmiş Milletler Çözüm Plânının Tam Metnini Açıklıyoruz", a.g.b., s. 6; Akpınar, a.g.m., s. 6; BMGK 789/1992..., a.g.e., s. 16; Deliceırmak, a.g.e., 1993, s. 96; Tamçelik, a.g.t., 2008b, s. 990.

62 "Set of Ideas on an Overall Framework Agreement on Cyprus", KKTC DSBA, a.g.b., md. 23; “Birleşmiş Milletler Çözüm Plânının Tam Metnini Açıklıyoruz", a.g.b., s. 6; Akpınar, a.g.m., s. 6; BMGK 789/1992..., a.g.e., s. 16; Deliceırmak, a.g.e., 1993, s. 96. 


\subsubsection{Askersizleștirme ve Silahsızlandırma Çalışmalarının Başlaması}

Bütünlüklü Çerçeve Anlaşması'nın onaylanmasından hemen sonra üç garantör devlet, Kıbrıs Rum ile Türk toplumlarından ve Kıbrıs'ta bulunan BM Barış Gücü'nden (UNFICYP) ${ }^{63}$ oluşan geçici bir 'Gözlem Komitesi' oluşturulacak ve bu komite, aşağıda verilen konulardan sorumlu olacaktır Buna göre Bütünlüklü Çerçeve Antlaşması'nın her iki toplum tarafından ayrı ayrı referandumlarla onaylanmasından hemen sonra bir tarafta Yunan ve Rum taburu ve ekipmanının, diğer taraftan da Türk ve Kıbrıs Türk taburu ve ekipmanının belli bir zaman dilimi içinde kabul edilen sayısal eşitliğe ulaşmasını denetlemek ve Federal Cumhuriyet'in kurulmasından önce belli bir zaman çizelgesi içinde Kıbrıs Rum ve Türk taburlarının kabul edilen düzeye indirilmesini ve İttifak Anlaşması'nda belirtilmeyen Kıbrıslı olmayan güçlerin tamamının çekilmesini denetlemektir. $^{64}$

Kısacası geçici düzenlemelerde yapılması gereken konuları Özetlemek gerekirse, Anayasa ve Seçim Kanunu'nun hazırlanması, federal bürokrasinin tesisi, emlâk taleplerinin çözümlenmesi, ekonomik gelişme ve koruyucu hükümlerin tespiti, toprak ayarlamaları ile ilgili düzenlemeler ve Fikirler Dizisi'ne ekli faaliyet programını hazırlamakla görevlendirilmiş bulunan iki toplumdan oluşan Komiteler tarafından faaliyete geçirileceği karara bağlanmıştır.

\subsection{Tarafların 'Geçici Dïzenlemeler' ile İlgili Tutumları}

Aslında tarafların, geçici düzenlemelerle ilgili tutum analizleri oldukça ilginç sonuçlar vermektedir. Zira geçici düzenlemeler, ilgili taraflar için bütünüyle tatminkâr edici olmaktan çok uzaktır. Buna göre 'al-ver' süreci içinde hazırlanan geçici düzenlemelerin nihaî amacı, Federal Kıbrıs Devleti'nin kurulmasını ve tarafların beklentilerini asgari düzeyde karşılanmasını sağlamaktır.

\subsubsection{Türk Tarafının Tutum Analizi}

Akademik

Türk tarafı, genel olarak geçici düzenlemelerle ilgili hükümleri, Kapsamlı Çerçeve Antlaşma'nın onaylanmasından sonra iki tarafın oluşturacağı 'Geçici Hükümet'in kurulmasıyla birlikte kabul edebileceğini açılamıştır. Aslında Türk tarafının bunu kabul etmesindeki sebep, önceden tahmin edilemeyecek birtakım talepleri önlemek içindir. Bununla birlikte Türk tarafı, Geçici Hükümet'in, her iki fe-
Cilt 8 Sayı 15 Kış 2014

63 "1990 Yılında Sunulan 27 Sayfalık Türk Önerileri”, KKTC CBA, a.g.b.; "Set of Ideas on an Overall Framework Agreement on Cyprus", KKTC DSBA, a.g.b., md. 63; "Birleşmiş Milletler Çözüm Plânının Tam Metnini Açıklıyoruz", a.g.b., s. 6; Akpınar, a.g.m., s. 6; BMGK 789/1992..., a.g.e., s. 16; Deliceırmak, a.g.e., 1993, s. 96.

64 Tamçelik, a.g.m., 2008a, s. 13-39; Soyalp Tamçelik, "Kıbrıs'ta Askersizleştirme Faaliyetleri ve Saldırmazlık Doktrinin Esasları", Uluslararası Sosyal Araştırmalar Dergisi, IV/17, (201 la), s. 348-377; Soyalp Tamçelik, "Kıbrıs'taki İngiliz Üslerinin Stratejik Önemi”, Uluslararası Insan Bilimleri Dergisi, VIII/1, (2011c), s. 1510-1539; Soyalp Tamçelik, "Kıbrıslı Rumların Bölge Barışını Tehdit Eden Silahlanma Çabaları", Turkish Studies International Periodical for the Languages, Literature and History of Turkish or Turkic, VI/3, (2011d), s. 391-424. 
dere devlet liderlerinin müşterek idaresiyle faaliyet göstermesini istemektedir. Ayrıca Türk tarafı, Kıbrıs Türk yasama kuvveti tarafından onaylanmadıkça, Kıbrıs Rum tarafının 1963 Aralığından sonra yapmış olduğu herhangi bir uluslararası anlaşmanın sonuçları ile kendi federe devletinin bağ $l 1^{65}$ sayılamayacağını ifade etmektedir.

Geçici düzenlemelerin uygulanmasıyla ilgili sürenin 18 ay olması, Kıbrıs meselesi gibi bir meselenin hâlli için yeterli olamadığı savunulmaktadır. ${ }^{66}$ Türk tarafınca bu süre, 3 ila 5 yıl arasından olması istenmektedir.

Bunun dışında Türk tarafının üzerinde önemli durduğu iki konu daha vardır. Biri toprak düzenlemeleri, diğeri de buna dayalı Gali haritasının coğrafik kriterleridir. ${ }^{67}$ Bunlar, anayasa ve egemenlik konularında uzlaşmaya varılmadan önce yapılması, Türk tarafı için ciddi bir zemin kaybına neden olabilecektir. Kaldı ki, toprak düzenlemelerinin yapıldığı bölgelerde Türk veya Rum idaresinin hangi şartlarda devam edeceğine dair belirsizlik, oldukça ciddi sıkıntılara yol açabilecektir. Bu sebeple toprak düzenlemesine tâbi olan bölgelerin, ilk günden itibaren BM'nin geçici yönetimine bırakılması çok daha iyi olacaktır. ${ }^{68}$

\subsubsection{Rum Tarafının Tutum Analizi}

Türk tarafı, geçici düzenlemelerle ilgili hükümlerin ayrıntılı bir şekilde müzakere edilmesini savunurken, Rum tarafı ise Genel Kurul'un kararlarına aykırı olduğu için 'KKTC'nin tanınmasının'69 söz konusu olmadığını ve Kapsamlı Çerçeve Antlaşması' na ilişkin olarak yapılacak ayrı referandumların BM tarafından yönetilmesini kabul ettiğini açıklamıştır. Ayrıca Rum tarafı, bu müzakereler sonunda çözüme varılsa bile, bu çözümün çok büyük bir ihtimalle yine geçici çözüm olacağını belirtmiştir. ${ }^{70}$ Dolayısıyla geçici düzenlemelerin getireceği geçici çözümün, adadaki Rum varlığını zedeleyebileceği göz önüne almaktadırlar.

Rum tarafının çekindiği bir diğer konu ise geçici düzenlemeler sürecinde 'Kıbrıs Cumhuriyeti'nin meşruiyeti ve egemenlik alanını kaydetmesidir. Çünkü bu

65 Tamçelik, a.g.m., 2009e, s. 55-84.

66 Tamçelik, a.g.t., 2008b, s. 992

67 Soyalp Tamçelik, “Birleşmiş Milletler Güvenlik Konseyi'nin Kıbrıs'la İlgili 789 Sayılı Kararı ve Buna Bağlı Toprak Hukuku", Proceeding of The Third International Congress For Cyprus Studies (III. Uluslararası Kıbrıs Araştırmaları Kongresi), Vol. III, Cyprus Issue and Tourism, Mağusa: Eastern Mediterranean University Center for Cyprus Studies Publications: 15, 2000, s. 391-418; Soyalp Tamçelik, "Kıbrıs'ta Gobi ve Gali Plânlarına Göre Harita Meselesi", Uluslararası Insan Bilimleri Dergisi, IX/2, (2012a), s. 1031-1074; Soyalp Tamçelik, "Kıbrıs'ta Toprak Düzenlemeleri ve Temel Kriterleri”, Türk Kültürü Araştırmaları M. Cihat Özönder Armağanı, TKAE Yayınları, Ankara, 2012c, s. 265-307; Soyalp Tamçelik, "Kıbrıs'ta Toprak Müzakereleri ve Tarafların Çözüm Kriterleri (19741990)", Uluslararası Sosyal Araştırmalar Dergisi, V/23, (2012d), s. 377-396.

68 Soyalp Tamçelik, "Kıbrıs'ta İç Göç Hareketleri ve Olası Bir Anlaşmada Etkileri”, Bilig Dergisi, 63, (2012b), s. 227-252.

69 BMGK $789 / 1992 \ldots$, a.g.e., s. 38.

70 Tamçelik, a.g.t., 2008b, s. 992.

Akademik Bakış 203 Cilt 8 Sayı 15 Kış 2014 
süreçte, Kıbrıs Cumhuriyeti'ni geçersiz kılacak birçok düzenlemenin var olduğunu iddia edilmektedirler. Bununla birlikte Rum tarafı, geçici düzenlemelerle ilgili olarak olması gereken, ama bahsedilmeyen bazı konulara da dikkat çekmiştir.

Buna göre Türk veya Rum bölgesinde görev alacak 'Geçici Hükümet memurları', çalışacakları bölgenin millî toplumuna mensup olmaları istenmektedir. Ayrıca Bakanlıklar, her iki toplum arasında eşit olarak paylaşılacak; ancak ilgili bakan ve yardımcısı aynı topluma mensup olmayacaktır. Bakan ile yardımcısı görevlerini yaparken birbirleriyle sıkı bir danışma ve işbirliği içinde olması ve alınan kararlarda konsensüsün sağlanması istenmektedir. Ancak ' $D_{l}$ şişleri Bakanlı̆̆ı'yla'71 ile ilgili kararlar, her şartta ve durumda iki toplum liderince imzalanıp yürürlüğe girmesi gerekecektir.

'Geçici Ortak Federal Hükümet'e açıça verilmeyen diğer görev ve yetkiler, Kıbrıs Türk ve Rum makamlarınca kendi ilgili bölgelerinde yapmaya, kullanmaya ve icra etmeye yetkili olacaklardır. Buna göre Dışişleri Bakanlığı hariç, Türk ve Kıbrıs Rum yönetimlerinin tüm bakanlıkları, kendi ilgili bölgelerinde faaliyet göstermeye aynen devam edebileceklerdir. ${ }^{72}$

Bu yüzden Kuruluş Antlaşması'nın yürürlüğe girmesinden en geç 30 gün sonra federe devletler, mevzuat uyarınca, yasama organlarının üyelerini ve diğer yetkilileri seçecekler, bununla birlikte seçilen yeni üyelerse, seçildikleri tarihten itibaren 10 gün içerisinde görevlerine başlayacaklardır.

Kıbrıs Federal Cumhuriyeti, müstakbel Anayasası konusunda ve iki millî toplum arasında bulanan ve çözümlenmemiş sosyal ve insanî konularda, ortak bir sekretarya kurulması kararlaştırılmıştır. ${ }^{73}$ Böylece Ortak Sekretarya, yukarıdaki konularda iki toplum lideri arasında varılan anlaşmaların uygulanmasında vasıta olabilecektir.

Bunun yanı sıra federal ortak hükümetin görev ve yetkileri, Federal Kıbrıs Cumhuriyeti Anayasası yazıldıktan sonra söz konusu Anayasa hükümleri uyarınca gözden geçirilmesi ve revizyona tâbi tutulması da elzem konulardan bi-

Akademik risidir. Buna ek olarak geçici düzenlemelerle ilgili yapılması gereken birçok husus daha vardır. Bunlar arasında yapılması gerekenlerin en önemlileri ise şunlardır: Kuruluş Antlaşması'nın sonuçlandırılması, federe devletlerin bayrak ve millî marş yarışmasının yapılması, federe devletlerin Anayasalarının ve mevzuatının belirlenmesi, güven artırıcı tedbirlerin yürürlüğe girmesi, BM Barış Gücü'ne bağlı birliklerin dolaşım özgürlüğünün sağlanması, Merkez Bankası'nın yürütme kuruluna dair seçimlerin yapılması, Geçici Yüksek Mahkeme yargıçlarının belirlenmesi, ithalât ve dağıtım lisanslarına ait kriterlerin belirlenmesi, kayıp

71 “BM Genel Sekreteri'nin Kıbrıs Özel Temsilcisi Weckman Aracılığı ile 18 Temmuz 1975'te Klerides'e Gönderdiği Mektup”, KKTC CBA, Dosya: Klerides'in Demeçleri, Tarih: 1975; Tamçelik, a.g.m., 2009e, s. 55-84.

72 Tamçelik, a.g.t., 2008b, s. 993.

73 Tamçelik, a.g.m. 2012c, s. 285-287. 
şahıslara ait akıbetin belirlenmesi, yedekler de dahil olmak üzere Kıbrıs Rum ve Türk kuvvetlerinin lağvedilmesi, Yunan ve Türk kuvvetlerinin yeniden düzenlenmesi, idarenin devredilmesi öncesinde toprak ayarlamalarına tâbi bölgelerden yapılacak sevkiyatın belirlenmesi, ayrı ayrı ve eş zamanlı gerçekleşecek referandumlarla ilgili yönetiminin sağlanması, Geçici Parlamento üyeliğinin belirlenmesi, geçici devlet başkanlıklarının tesisi ve geçici hükümet ve organlarının seçimi veya işlemlerinin yapılmasının sağlanması sayılabilir. ${ }^{74}$ Dolayısıyla bütün bunlar, geçici dönemle ilgili olarak yapılması gereken işlemler olarak ifade etmek mümkündür.

\subsection{Gali Fikirler Dizisi'ne Göre Referandum Süreci}

Referandum, çağdaş siyasal yaşamda önemli bir enstrüman olarak kullanılan bir araçtır. Hele çağdaş demokrasilerde bu araca başvurulması, farklı özelliklerden kaynaklandığı görülmektedir. ${ }^{75}$ Gelişmiş demokrasilerde ve toplumlarda, biri anayasal referandum, ikincisiyse yasamaya ilişkin referandum araçları kullanılmaktadir.

Aslında birinci tip referandum, daha çok Fransa'da uygulanmış ve orada gelenekselleşmiştir. Buna karşın referandum, kanunların halk tarafından yapılması veya yönetime doğrudan katılması için tanınan vasıtalardan birisi olarak karşımıza çıktığı görülmüştür. Özellikle bu vasıtaya en çok hükümetler başvurmuşlardır. ${ }^{76}$ Dolayısıyla referandum, kamu yararına olan önemli sorunların çözümünü kolaylaştırmak ve halkın fikrini öğrenmek için hükümetin ara sıra başvurduğu bir prosedür olarak değer kazanmıştır. Fakat gerçek kamuoyunu öğrenebilmek için son derece dikkatli olunması gerekmektedir. Zira referandumların güvenilir olabilmesi için tarafsız olması, iktidardaki hükümetin sorulacak soruları kendi çıkarlarına uygun bir biçimde düzenleme serbestîsine sahip olmaması ve tek bir soru sorulması gerekmektedir. ${ }^{77}$ Bir yönüyle referandumlar, mantık ve muhakeme gücü gerektiren önemli derecede sınavdırlar.

Oysa seçmenler aniden, hükümetler içinse kasten sorma eğiliminde olduğu birçok soruya, tek bir cevap aramaktadırlar. Bu yüzden verilen tek bir cevap, genel bir siyasî sorunun cevabı olduğu kadar, kamuoyuna başvurulan problemin yarattığı ortamın da cevabı olarak kabul edilmesi gerekmektedir. Bu nedenle toplumlarda, referanduma duyulan güven giderek azalmaktadır. Fakat 'iyi' veya 'kötü', 'güvenilir' veya 'güvenilmez'78 olsun, bir kez referandum prensibine inanıldı mı, aksine davranmak pek de doğru bir yaklaşım değildir.

74 Tamçelik, a.g.t., 2008b, s. 993-994.

75 Jean Marie Cotteret ve Claude Emeri, Seçim Sistemleri, (çev. Ahmet Kotil), Presses Universitaires de France, İletişim Yayınları, İstanbul, 1995, s. 30.

76 "Demokrasi", Temel Britannica, 1994, s. 179

77 Servet Sami Dedeçay, Kıbrı'ta Enformasyon veya Yazılı ve Sözlü Basın, Cilt: 1., Lefkoşa Özel Türk Üniversitesi Yayınları: 5, Gelişim Ofset, Lefkoşa, 1988, s. 20.

78 Dedeçay, a.g.e., s. 20.

Akademik Bakış 205 Cilt 8 Sayı 15 Kış 2014 
Bütün bunlardan hareketle Gali Fikirler Dizisi'nde referandum sürecinin belirlenmesi ve belli bir takvime bağlanması boşuna değildir. Buna göre Bütünlüklü Çerçeve Antlaşması, her iki toplum liderinin de katılacağı uluslararası nitelikli zirve toplantısından sonra 30 gün içinde ve her iki toplumda ayrı ayrı referandumlar yapılması için kararlaştırılmıştır.

Bütünlüklü Çerçeve Antlaşması özellikle her iki toplum tarafından ayrı ayrı referandumlarla onaylandıktan ve geçiş dönemi ile ilgili düzenlemelerin yerine getirilmesinden sonra bu süreç, yeni bir ortaklıkla sona ereceği tasarlanmıştır. ${ }^{79}$ Ayrıca uygun bir takvimde, Federal Anayasa'nın ve resmi seçimlerin yapılması ve bunun, ayrı ayrı referandumlarla onaylanması da teyit edilmiştir. ${ }^{80}$

Federal Anayasa'nın teknik yöndeki hazırlıklarının tamamlanması ve Geçici Hükümet'le, ilgili federe devletlere ait Meclislerinin onaylanması ile ilgili işlemler, referandum sürecinden sonra yapılacağı kararlaştırılmıştır. ${ }^{81}$ Böylece Federal Anayasa, iki tarafta da yapılacak ayrı referandumlardan sonra yürürlüğe girecektir.

Kısaca bir yandan geçici düzenlemelerin usulünü tespit etmek, diğer yandan da kurulması kararlaştırılan ikili komitelerin programlarına uygun biçimde çalışmasını sağlamak ve denetlemek amacıyla, her iki toplum liderlerinin ve BM Genel Sekreteri' nin temsilcilerinin katılacağı bir komite kurulmasını zorunlu kılacaktır. Ayrıca bu Komite, zirve toplantısı tarihinden itibaren 30 gün içinde Kapsamlı Çerçeve Antlaşması'nın onaylanmasına ilişkin referandumları da yapacaktır. ${ }^{82}$ Bunun dişında bu komite, Anayasa'yla ilgili diğer referandumları da yapacağı kararlaştırılmıştır. Ancak bu sürecin, başından sonuna kadar BM yetkilerinin gözetiminde uygulanacağı da belirtilmiştir.

Aslında plana göre anlaşmanın hukuken geçerlilik kazanabilmesi için her iki halkın ayrı ayrı sandığa gidip, her iki tarafta da bu anlaşmaya çoğunlukla 'evet'83 demesiyle mümkün olacaktır. Referandum sonucunda, Rum halkı anlaşmayı kabul eder, Türk halkı reddederse, anlaşma hiçbir hukukî sonuç doğurmayacak ve gündemden düşecektir. Pek tabî̂ ki bunun tersi de aynı sonucu

Akademik doğuracaktır. Yani bir başka deyişle yapılacak referandumlar, her iki tarafça da onaylanmadı̆̆ı sürece, hiçbir yasal geçerliliği olmayacaktır. ${ }^{84}$

79 "Set of Ideas on an Overall Framework Agreement on Cyprus", KKTC DSBA, a.g.b.; "Set of Ideas on an Overall Framework Agreement on Cyprus", KKTC CBA, a.g.b.; BMGK 789/1992..., a.g.e., s. 17.

80 "Birleşmiş Milletler Çözüm Plânının Tam Metnini Açıklıyoruz", a.g.b., s. 6; "Set of Ideas on an Overall Framework Agreement on Cyprus", KKTC CBA, a.g.b., md. 95; Akpınar, a.g.m., s. 6.

81 "1990 Yılında Sunulan 27 Sayfalık Türk Önerileri”, KKTC CBA, a.g.b., s. 6; "TBMM'nin 10 Haziran 1993 Tarihinde "Kıbrıs Sorunu” ile İlgili Olarak Oy Birliğiyle Onayladı̆̆ı Tarihi Bildiri”, Tutanak Dergisi, 10 Haziran 1993, s. 303; BMGK 789/1992..., a.g.e., s. 28.

82 Kıbrıs Sorunu, Türkiye Barolar Birliği Yayınları, Sevinç Matbaaları, Ankara, 1975, s. 12.

83 Sedat Ergin, “70 Bin Rum, Türk Bölgesine Geçebilir-3”, Hürriyet Gazetesi, 21 Kasım 2002, No:122354, s. 18.

84 Tamçelik, a.g.t., 2008b, s. 996. 
Buna göre planın giriş bölümünde, her iki toplum liderleri anlaşmanın ardından yapılacak zirve toplantısından tam ve en geç 30 gün içerisinde referandumların yapılmasını âmir hüküm olarak belirlemiştir. Belgenin Bü̈ünlüklü Hedefler bölümünün birinci paragrafı, liderlerin anlaşmasından 30 gün sonra yapılacak referandumla alınacak onaydan hemen sonra Geçici Düzenlemelere geçileceğini ve Türkler açısından hayatî öneme haiz maddelerin üç kişilik bir komite $e^{85}$ tarafından fiilî bir şekilde kararlaştırılarak, iki toplumu da bağlayıcı hâle geleceği âmir hüküm hâline getirilmiştir. Ayrıca belgenin Geçici Düzenlemeler başlıklı bölümünün birinci paragrafında, oluşturulacak komitenin basit çoğunlukla karar alma yetkisine haiz olduğu, uygulama kuvvetine sahip bulunduğu ve uygulamalarını 18 ay içinde yapacağı kararlaştırılmıştır. Adı geçen belgenin 3. paragrafında ${ }^{86}$ ise alınan kararlardan ve uygulamalardan sonra BM'nin organize edeceği zaman ve şekilde, referandumlara gidileceği âmir hüküm hâline getirilmiştir.

Ne var ki Gali belgesinde, nihaî anlaşmanın referandumlarla toplumların onayına sunulacağı dört ayrı yerde ifade edilmişse de bu dört ayrı referandum için dört ayrı zamanda yapılacağından söz edilmemiştir. ${ }^{87}$ Belgede sözü edilen ilk referandum, onaydan hemen sonra, yani Geçici Düzenlemeler bölümünde hükme bağlanmıştır. Geçici Düzenlemeler bölümü incelendiğinde görülmektedir ki, referandumda onay alınır alınmaz KKTC, Kıbrıslı Türkler indinde varlığını hukukî olarak kaybetmekle kalmayacak, federe bir devlet özelliğine de kavuşmuş olmayacaktır. Zira Federal Anayasa'nın hazırlanıp yürürlüğe konması, federal düzeydeki kamu hizmetinin oluşturulması, mülk ve yerleşim iddiaları çerçevesinde uygulamaların başlaması ve yeni güvenceler konusunda mutabık kalınması KKTC'nin mevcudiyetini tehlikeye sokacaktır. ${ }^{88}$ Dolayısıyla bu durum, Türk siyasal erkini tedirgin eden bir olgu olarak ortaya çıkmaktadır. Buna benzer bir durumu da Kıbrıslı Rumlar için geçerlidir. Zira olası bir federal sistemin çalışmaması halinde mevcut olan Kıbrıs Cumhuriyeti'nin meşruiyeti zedelenecek ve yıllardır yaşatmaya çalıştıkları bu devletin bekası tehlikeye girecektir. Bu yüzden her iki taraf da prensip olarak bu düzenlemelere karşıdırlar. Ancak uluslararası baskı neticesinde her iki taraf da uzlaşır gibi görünmekte ve suçu bir diğerine atarak bu baskıdan kurtulmaya çalışmaktadırlar.

\subsubsection{Gali Fikirler Dizisi'ne Göre Tarafların Referandumla İlgili Tutumları}

Gali Fikirler Dizisi'ne göre tarafların referandum sürecine bakışları birbirinden farklıdır. Aslında bu farklılık, onların siyasal düşüncelerinden değil, daha çok korkularından ve endişelerinden kaynaklanmaktadır. Gerçi tarafların endişe-

85 Cumhur Deliceırmak, "Sinsilik", Birlik Gazetesi, 3 Ocak 1992, No:526, s. 11; Deliceırmak, a.g.e., 1993, s. 96.

86 Deliceırmak, a.g.m., 1992, s. 11; Deliceırmak, a.g.e., 1993, s. 96

87 Tamçelik, a.g.t., 2008b, s. 996.

88 Tamçelik, a.g.t., 2008b, s. 996

Akademik Bakış 207 Cilt 8 Sayı 15 Kış 2014 
lerini irdelemek veya yanlışlamak, bir yöntem olarak görülse de vaka olarak değerlendirildiği zaman göz ardı edilmemesi gereken gerçekler olarak ortaya çıkmaktadırlar. Buna göre tarafların, referandumla ilgili tutum analizlerini şu şekilde değerlendirmek mümkündür.

\subsubsection{Türk Tarafının Tutum Analizi}

Türk tarafı, üzerinde anlaşılan metinlerin, tartışılmak ve Türk ve Rum halklarının onayını almak için her iki tarafta da ayrı ayrı yapılacak referandumlara sunulmak üzere Kıbrıs Türk ve Kıbrıs Rum yasama meclislerine sunulmasını istemektedir. ${ }^{89}$ Böylece kalıcı çözüm, sağlam temellere dayandırılmış olacaktır. Bunun için tercih edilecek en iyi yol, Federal Anayasa'nın iki tarafta da yapılacak referandumlarla onaylandıktan sonra yürürlüğe girmesidir. ${ }^{90}$ Zaten Türk tarafınca bu durum, KKTC Cumhuriyet Meclisi'nde alınan 18 Mayıs 1993 tarih ve 112/3/1993 karar numarasiyla ve 18 Haziran 1993 tarih ve 117/3/1993 karar numarasıyla tespit edilmiştir.91

Aslında Meclis'in, Kıbrıs'taki iki halkın iradesinin esas olduğunu ve bulunacak çözüm şeklinin Kıbrıs'ta yaşayan her iki halkın ayrı ayrı referandumlarla yürürlüğe gireceğini teyit etmesi dikkat çekicidir. ${ }^{92}$ Zira KKTC'de 1990 yılından beri yürürlükte olan bir yasaya göre bunun yapılması hukukî bir zorunluluktur. Özellikle ilgili yasanın 3. maddesinde "KKTC'nin egemenliğine ve uluslararası varliğına sınırlamalar getirecek olan anlaşmalardaki temel ilkelerin, anlaşmaların imzalanmasindan veya onaylanmalarının Cumhuriyet Meclisi tarafindan bir yasa ile uygun bulunmasından önce halkoylamasina sunulması zorunludur"93 denmektedir. Dolayısiyla bulunacak bir çözümün mutlak surette halka sorulması gerekmektedir. Ancak halka sorabilmek ve referandum yapabilmek için her şeyden önce ortada mutabık kalınan bir metnin olması gerekmektedir. Dolayısıyla Kıbrıslı Türklere göre bulunacak olası bir anlaşma, gönüllülük esasına dayanması ve her iki halkın ayrı ayrı referandumlarla gerçekleştirilmesini zorunlu kılmaktadır. ${ }^{94}$

\subsubsection{Rum Tarafının Tutum Analizi}

Rum muhalefet partilerinin büyük bir çoğunluğu, Kıbrıs Rum liderinin imzalayacağı bir anlaşmayı halkın onayına sunmak için referanduma götürülmemesi gerektiğini ifade etmiştir. Çünkü Rum siyasî partileri, Rum liderliğinin imzala-

89 “Kıbrıs Türk Tarafının Bir Bütünün Parçasını Teşkil Eden Federal Yasama Organı ile İlgili Yaklaşım", KKTC CBA, Dosya: Türk Önerileri, Tarih: 30 Ocak 1989.

90 Cerrahoğlu, a.g.e., s. 258-259

91 "KKTC Cumhuriyet Meclisi Kararları", KKTC CBA, Dosya: Karar Defteri, Tarih: 18 Mayıs 1993112/3/1993 ve 18 Haziran 1993-117/3/1993 numaralı kararlar.

92 Sabahattin, a.g.m., 1998a, s. 259.

93 Oktay Ekşi, “Kıbrıs'ta Son Tango", Hürriyet Gazetesi, 26 Ocak 2003, No:302564, s. 23.

94 Sabahattin, a.g.m., 1998a, s. 430; Rauf Raif Denktaş, Kıbrıs Meselesinde Son Durum, Raif Denktaş Eğitim Vakfı Yayınları No: 2, Lefkoşa, 1996, s. 12. 
yacağı bir anlaşmanın, önce kendilerince onaylanmasını, sonra da halkın iyice aydınlatılmasını gerekli görmektedirler.

Aslında bu konu, siyasî parti liderleri arasında yapılan görüşmelerde de ele alınmıştır. Buna göre Rum siyasî partileri, özellikle halkın bu anlaşmayı reddetmesi hâlinde bile, anlaşmanın altındaki imzadan dolayı Rum tarafını bağlayacağını düşünmektedirler. ${ }^{95}$ Bundan başka halkın anlaşmayı küçük bir çoğunlukla kabul etmesi hâlinde ise iç cephede ciddi bir bunalım yaratılacağından da korkmaktadırlar. Bundan dolayıdır ki Rum siyasî partileri, önce kendileri tarafından onaylanmayan bir anlaşmanın, doğrudan halkın onayına sunulmaması ve referanduma da bu yüzden götürülmemesi gerektiğini belirtmişlerdir.

Güney Kıbrıs'ın en büyük siyasî partilerinden biri olan Rum Demokratik Birlik Partisi'nin (Disí) eski Genel Başkanı Glafkos Klerides, New York'ta yapılan görüşmelerden bir sonuç çıkması durumunda, bunun imzalanmamasını, yapılması gereken şeyin sadece parafe edilmesi ve imza için halkoyuna ${ }^{96}$ gidilmesi gerektiğini ifade etmiştir.

Aslında Kıbrıslı Rumların tutumunu en iyi ifade eden, yine de Vasiliu olmuştur. Buna göre Vasiliu, çift referandum konusunda şunları ifade etmiştir: "Bence, ayr referandumlar düzenlenmesi gereklidir. Çünkü biz, Kibris'in nüfusunun tahminen \% 80'inini oluşturduğumuz için, hepimiz de varlacak bir anlaşmanın lehinde oy kullandığımız zaman, Kibrıslı Türklerin hepsi de anlaşmanın aleyhinde oy kullansalar bile, yine bizim dediğimiz olur. Ama böyle olunca Kıbrıs sorunu çözümlenmiş olur mu? Olmaz... Çözüme ulaşmış olmak için her iki toplumda da çoğunluğun belirleyeceği görüşe saygı gösterilmesi gerekir. Aksi takdirde kendi kendinizi aldatmış olursunuz. Ben, işte bu nedenlerden dolayı, ayrı referandumların düzenlenmesinden yanayım." ${ }^{97}$ demiştir.

Ancak BM Genel Sekreteri 26 Şubat 1990 tarihinde yaptığı konuşmada, Kıbrıs'ın iki toplumun vatanı olduğunu, sayıca daha fazla olan tarafın sayıca az olan tarafa kendi görüşlerini zorla kabul ettirmeye hakkı bulunmadığını teyit etmiştir. ${ }^{98}$ Bu nedenledir ki, kapsamlı anlaşmaya ulaştıktan sonra her iki tarafa da bu anlaşmayı kabul edip etmediklerinin sorulması gerektiğini belirtmiştir. Aslında bu dahi Türklere azınlık gözü ile bakılmadığının ciddi bir işaretidir. Ancak anlaşmanın reddedilmesinin, Taksim için bir neden olamayacağı da belirtilmiştir. Dolayısıyla hiçbir şekilde Taksim'i kabul etmeyeceklerini ifşa etmişlerdir.

Yukarıda da görüleceği gibi Kıbrıslı Rumlar, çift referanduma sıcak bak-

95 "Referanduma Fırsat Verilmeyecek", Agon Gazetesi, 7 Eylül 1992, No:3002, s. 4; "Rum Basın Özetleri", KKTC CBA, Dosya: Rum Basın Özetleri, Tarih: 7 Eylül 1992, s. 4.

96 Doğan Uluç, “New York'ta Harita Pazarlığı”, Hürriyet Gazetesi, 21 Haziran 1992, No:75524, s. 12.

97 Rauf Raif Denktaş, Dünü Bugünü Yarını ile Kıbrıs Davamız, Lefkoşa, 1991, s. 6.

98 Kıbrıs Sorunu Gelişmeler ve Görüşmeler, SiSAV Yayınları, Reyo Matbaacılık, İstanbul, 1990, s. 69.

Akademik Bakış 209 Cilt 8 Sayı 15 Kış 2014 
maktadırlar. Ama referandum sürecinde adaya gelen Türk vatandaşlarının veya onların tabiri ile 'yerleşiklerin' oy kullanmaları kabul edilebilecek bir şey değildir. Kaldı ki Rumlar, sadece 20 Aralık 1963 tarihinde Kıbrıs vatandaşı olan Türkler ile 18 yaşındaki evlâtlarının, ${ }^{99}$ referandumda oy kullanmasını istemektedirler.

Ayrıca her iki taraf için aşağıdaki soruların yöneltileceği bir referandum düzeninin kurulmasını savunmaktadırlar. Buna göre:

'i. Federal Kıbrıs Anayasası'nı içeren Kuruluş Anlaşması ve tüm ilâvelerini onaylıyor musunuz?

ii. Federal devletin anayasasını ve federe devletler için yürürlükte olacak mevzuata ilişkin hükümleri onayliyor musunuz?

iii. Kıbrıs'taki yeni düzenle ilgili konulara ilişkin Kıbrıs, Yunanistan, Türkiye ve Birleşik Krallik arasinda yapilacak olan taslak antlaşmayı onayliyor ve bu antlaşmanın imzalanmasini talep ediyor musunuz?

Evet / / Hayır / /1100 sorusunun sorulması gerektiğini önermektedirler.

\section{Annan Planı'na Göre Geçici Dönemle İlgili Birtakım Düzenlemeler}

2002-2004 yılları arasında Kıbrıs'ta kurulmak istenen siyasal düzenin müzakereleri yapılmıştır. Bu süreç zarfında birçok tartışmalar yapılmış ve 31 Mart 2004 tarihinde nihaî belge niteliğinde bir metin ortaya çıkmıştır. Bu metne göre kurulacak federal sistemde Geçici Dönem'le ilgili olarak bir dizi karar alınmıştır. Özellikle bu kararların ekseriyeti, taraflar arasında çıkabilecek sorunları önlemek, olumsuz tesirleri azaltmak ve sürdürülebilir bir düzenin devamını sağlamak yönünde olduğu görülmüştür. Buna göre Annan Planı'nda Geçici Dönem'le ilgili olarak alınan kararların bazıları şu şekilde zikredilmiştir.

Anlaşma metninin 'Ana Maddeler' başlığı altındaki bölümün 7. maddesine göre geçici federal ve kurucu devlet kurumlarının nasıl şekilleneceği belirtilmiştir. Buna göre Kıbrıs'ta kurulacak federal kurumlar, Kuruluş Antlaşması'nın yürürlüğe girmesiyle yerlerini alacağı ve bu kurumların geçiş dönemi süresince, faaliyetlerini yerine getireceği ifade edilmiştir (md. 7/1).

Buna karşın Annan Planı'na göre kurucu devletlerin uhdesinde kurulacak geçici yasama, yürütme ve yargı organları anlaşmanın yürürlüğe girmesiyle birlikte hayata geçeceği tasarlanmıştır (md. 7/2). Buna karşın federal devletin yürütme erki olarak geçici hükümetin oluşumunda altı üyeli ${ }^{101}$ Bakanlar Kurulu'ndan

99 Kıbrıs Rum Kesimi Cumhurbaşkanı Glafkos Klerides'in BM Genel Sekreteri Kofi Annan'a sunduğu 4 Aralık 2002 tarihli mektubundan tercüme edilmiştir. Ayrıca bkz... Efegil, a.g.e., s. 42.

100 “10 Aralık 2002 Tarihli Kıbrıs Sorununun Kapsamlı Çözümü Iç̧in Anlaşma Temeli - Annan Plan for Cyprus Settlement - Full Text 10 December 2002", KKTC CBA, Dosya: Annan Planı, Tarih: 2002.

101 Annan Planı'na göre Bakanlar Kurulu üç Kıbrıslı Rum ve üç Kıbrıslı Türk'ten oluşmaktır. Bunun için bkz... "Kıbrıs Sorununun Kapsamlı Çözümü - 30 Mart 2004", KKTC CBA, Dosya: BM Önerileri Annan Plânı, Tarih: 30 Mart 2004. 
oluşacağı ve geçici dönemle ilgili kararların ivedilikle alınıp uygulanacağı da belirtilmiştir (md. 7/2). Ancak federal düzeydeki Başkanlık ve Başkan Yardımcılı̆̆ makamları 'Başkanlık Konseyi'nin ilk döneminde her on ayda bir rotasyona tâbi olacağı kararlaştırılmıştır (md. 7/3).

Bunun dışında kurucu devlet sınırları ve toprak ayarlamaları (md. 9) ile ilgili bölümde kurucu devletlerin sınırları belirtilmiş ve anlaşmanın bir bölümünü oluşturan haritanın tasvir edildiği görülmüştür. Buna göre anlaşmanın yürürlüğe girmesini müteakip, toprak ayarlaması sonucu yasal olarak Kıbrıs Rum Devleti'ne ait olan bölgelerin idaresi üç yılı geçmeyecek geçici bir süre için Kıbrıs Türk Devleti'nde olacağı kararlaştırılmıştır (md. 9/2). Ne var ki Kıbrıs Rum Devleti'ne devredilecek bölgelerin idaresi, Anlaşmanın yürürlüğe girmesini müteakip 104 gün içerisinde ve altı safha halinde devredilmesi tasarlanmıştır. Altı safhalık bu süreç, 42 aylık bir süre için söz konusu olacak ve ilgili kurucu devlete bitişik olan ve büyük ölçüde yerleşime açı olmayan bölgelerin idaresinin Rum Devleti'ne devredilmesi istenmiştir. Ancak devir işleminin BM gözetiminde olacağı ifade edilmiştir (md. 9/2).

Annan Planı'nın 'Geçici Hükümler' adlı VII. bölümünde ise kurucu devletlerin yasama, yürütme ve yargı gibi geçici organları, kurucu devlet anayasalarına ve Kıbrıs meselesinin kapsamlı çözümü çerçevesindeki yükümlülüklere uygun olarak Kurucu Antlaşma'nın yürürlüğe girmesiyle çalışmaya başlayacağı bildirilmiştir (md. 38/1). Özellikle 13 Haziran 2004 tarihinde, kurucu devletlerin halkoyu ile seçilen tüm makam sahipleri, federal ve Avrupa Parlamentoları için ayrı ayrı düzenlenecek seçimlerle, aynı anda seçilecekleri kararlaştırılmıştır (md. 38/2). Buna karşın her kurucu devletin yeni seçilmiş yasama organı, Kuruluş Antlaşması'nın yürürlüğe girdiği tarihten itibaren, kendi üyeleri arasından 24 üyeyi federal parlamentoya delege olarak atayacağı, bu bağlamda kurucu devletteki yasama organında her siyasal grup o yasama organı içindeki gücü oranında delege seçeceği ve buna ilaveten, Avrupa Parlamentosu'na, Kıbrıs Rum Devleti dört ve Kıbrıs Türk Devleti ise iki delege göndereceği belirtilmiştir (md. 39/1). Ancak geçici parlamento, Federal Parlamento'nun anayasal fonksiyonlarını ve imtiyazını, bu Anayasa'daki Senato ile ilgili usul hükümlerine uygun olarak yerine getireceği kararlaştırılmıştır (md. 39/2).

Geçici devlet başkanı ile ilgili hükümler ise 40. maddede belirtilmiştir. Buna göre yeni seçilen Federal Parlamento Başkanlık Konseyi'ni, seçene kadar Devlet Başkanı makamı, Eşbaşkanlı̆̆ın uhdesine bırakılacağı (md. 40/1), Eşbaşkanlar başarılı referandum sonrasında, iki günden daha geç olmamak kaydıyla BM Genel Sekreteri'ne isimleri bildirilen kişilerin veya böyle bir bildirim olmadığ hallerde, kurucu devletlerin hükümet başkanları olacağı (md. 40/2), herhangi bir Eşbaşkanın istifası veya görevini yerine getiremeyecek durumda olması halinde, ilgili kurucu devletin yasama organı onun yerine başka birini seçeceği (md. 40/3) ve Eşbaşkanlığın devletin başı olarak temsiliyeti, nüfusu en fazla

Akademik Bakış 211 Cilt 8 Sayı 15 Kış 2014 
olan kurucu devletten gelen Eşbaşkan'dan başlamak üzere her takvim ayında değişeceği kararlaştırılmıştır (md. 40/4). Bir başka deyişle ilk seçilen Başkanlık Konseyi, tüm fonksiyonlarını Anayasa hükümlerine uygun olarak yerine getireceği, Cumhurbaşkanı ve Cumhurbaşkanı Yardımcısı görevinin, seçilen iki üye arasında ve her on ayda bir dönüşümlü olarak yerine getireceği ifade edilmiştir (md. 41/5). Ancak Kurucu Devlet'in Hükümet Başkanları'nın Başkanlık Konsey toplantılarına katılımı, ilk 10 yıl boyunca, kurucu devletlerin hükümet başkanları, oy hakları olmadan, Bakanlar Kurulu toplantılarına ve daha sonra Başkanlık Konseyi toplantılarına katılmak üzere davet edileceği kararlaştırılmıştır (md. 42).

Buna karşın Birleşik Kıbrıs Cumhuriyeti'nin geçici bağımsız görevlileri, Başkanlık Konseyi'nin Anayasa'ya uygun olarak atamasına kadar, 31 Temmuz 2004 tarihinden geç olmamak üzere görev yapacakları (md. 43/1) ve Birleşik Kıbrıs Cumhuriyeti'nin geçici Başsavcısı, Kıbrıs Türk Devleti'nin Başsavcısı ve Birleşik Kıbrıs Cumhuriyeti'nin geçici Başsavcı Yardımcısı Kıbrıs Rum Devleti'nin Başsavcı Yardımcısıdır. Ancak bu görevliler, Anayasa çerçevesindeki fonksiyonlarını yerine getirirken oybirliğiyle karar alacakları belirtilmiştir (md. 43/2). Birleşik Kıbrıs Cumhuriyeti'nin geçici Sayıştay Başkanı ise Kıbrıs Rum Devleti'nin Sayıştay Başkanı ve Birleşik Kıbrıs Cumhuriyeti'nin geçici Sayıştay Başkan Yardımcısı, Kıbrıs Türk Devleti'nin Sayıştay Başkanı olacağı ve Anayasa çerçevesindeki fonksiyonlarını yerine getirirken oybirliğiyle karar alacakları tespit edilmiştir (md. 43/3). Geçici federal hükümet ile ilgili hususlar zikredildiği zaman yeni seçilen federal Parlamento, Başkanlık Konseyi'ni seçene kadar, Bakanlar Kurulu, Bir leşik Kıbrıs Cumhuriyeti'nin hükümeti görevini yürüteceğini (md. 41/1), Kurucu Antlaşma'nın yürürlüğe girmesi üzerine, Bakanlar Kurulu üyeleri, referandumlar sonrasında, iki günden daha geç olmamak kaydıyla BM Genel Sekreteri'ne isimleri bildirilen kişilerden oluşacağı (md. 41/2), Bakanlar Kurulu'nun Kıbrıslı

Akademik Rum üyeleri $A B$ işleri, Maliye, Adalet ve İcişleri Bakanlıklarına başkanlık edeceği (md. 41/3) ve Bakanlar Kurulu'nun Kıbrıslı Türk üyeleri Ulaştırma ve Doğal Kaynaklar, Dışişleri ve Savunma ile Ticaret ve Ekonomi Bakanlıklarına başkanlık edeceği (md. 41/3) de belirtilmiştir.

Birleşik Kıbrıs Cumhuriyeti'nin Merkez Bankası'nın yönetim kurulu üyeleri ise Kuruluş Antlaşması'nın yürürlüğe girmesiyle birlikte atanacağını ve BM Genel Sekreter'e Kuruluş Antlaşması'nın yürürlüğe girmesinden önce isimleri bildirilen Kıbrıslı ve Kıbrıslı olmayan kişilerden oluşacağı kararlaştırılmıştır (md. 44/1). Merkez Bankası Başkan ve Başkan Yardımcısı ile diğer Yönetim Kurulu Üyeleri, Kuruluş Antlaşması'nın yürürlüğge girmesiyle birlikte görevlerine başlayacağı ve Yönetim Kurulu'na ve Anayasa'daki Para Politikası Komitesi'ne ait Anayasa'daki yetkileri, Para Politikası Komitesi göreve başlayana kadar yürüteceği belirtilmiştir (md. 44/2). 
Geçici Hükümler bölümünün Yüksek Mahkeme Yargıçları ile ilgili kısmında yargıçlar ve mahkeme mukayyitleri ile ilgili birtakım bilgiler de bulunmaktadır. Buna göre Kuruluş Antlaşması'nın yürürlüğe girmesiyle birlikte atanacağı ve BM Genel Sekreter'e Kuruluş Antlaşması'nın yürürlüğe girmesinden önce isimleri bildirilen Kıbrıslı ve Kıbrıslı olmayan kişilerden oluşacağı belirtilmiştir (md. 45/1). Anayasa Mahkemesi üyeleri olarak görev yapacak Yüksek Mahkeme yargıçları, Kuruluş Antlaşması'nın yürürlüğe girmesiyle birlikte görevlerini üstleneceklerini ve 36 takvim ayı süreyle, Federal Parlamento'nun özel çoğunlukla alacağı bir kararla görev süreleri uzatılmadıkça, aynı görevde kalacakları kayda alınmıştır (md. 45/2). Buna ilaveten Yüksek Mahkeme'nin Kıbrıslı olmayan mukayyidi ve iki mukayyit yardımcısı, Kuruluş Antlaşması'nın yürürlüğe girmesiyle birlikte görevlerine başlayacakları ve yasaya uygun olarak değiştirilene kadar 36 takvim ayı süreyle görevde kalacakları kararlaştırılmıştır (md. 45/3).

Birincil Federal Yargı Mahkemesi'nde görev alacak yargıçlar ise Başkanlık Konseyi tarafından atanacakları, ancak bu zamana kadar, Yüksek Mahkeme'nin diğer yargıçları Birincil Federal Yargı Mahkemesi'ne ait fonksiyonları yürütecekleri belirtilmiştir (md. 45/4). Eğitim hayatı ile ilgili olarak yapılacak düzenlemelerde, resmi dil eğitiminin nasıl yapılacağı da belirtilmiştir. Buna göre Birleşik Kıbrıs Cumhuriyeti'nin resmi dillerinin (Türkçe ve Yunanca) ortaokul öğrencilerine öğretilmesine yönelik zorunlu eğitim, Kuruluş Anlaşması'nın yürürlüğe girmesinden sonra en geç üç yıl içinde başlayacağı ifade edilmiştir (md. 50.).

Devlet malları ile ilgili prensiplere gelince, Federal Anayasa'nın ilişiğginde sunulan federal mülkiyet dışındaki kamu malları, mülkiyetin bulunduğu kurucu devlete ait olacağı kararlaştırılmıştır (md. 51/1). Eşbaşkanlar ve kurucu devletin hükümet başkanları, Kuruluş Antlaşması'nın yürürlüğe girmesini müteakip üç aydan geç olmamak kaydıyla federal malların listesi konusunda mutabakata varacağını, şayet mutabakata varamazlarsa, geçici Yüksek Mahkeme ilgili tarafların temsiliyetlerine dayalı olarak uygun liste konusunda karar vereceğini, aksine karar alınmadıkça söz konusu mallar Kuruluş Antlaşması'nın yürürlüğe girdiği tarihten itibaren federal mal olarak kabul edileceğini belirtmiştir (md. $51 / 2)$.

Geçici Hükümlerin bir diğer önemli konusu ise uluslararası askerî operasyonlarla ilgilidir. Buna göre Türkiye'nin AB'ye girinceye kadar, Birleşik Kıbrıs Cumhuriyeti, Yunanistan ve Türkiye'nin ve buna ek olarak her iki kurucu devlet hükümetlerinin rızası olmaksızın topraklarını uluslararası askerî operasyonların kullanımına açmayacağı da kararlaştırılmıştır (md. 53). Böyle Kıbrıs, mekân olarak uluslararası askerî operasyonların dışından tutulabilecektir. Ancak Ingiliz üs bölgeleri ${ }^{102}$ için aynı durumun söz konusu değildir. 
Annan Planı'nın Ek VI bölümünde toprak düzenlemeleri ile ilgili olarak birtakım yükümlülükler de bulunmaktadır. Buna göre kurucu devlet sınırlarının belirlenmesi konusunda ise kurucu devletlerin sınırları, Federal Anayasa'ya ekli haritada gösterildiği gibi, detaylı bir şekilde tanımlanmıştır. Bu sınırlar içerisinde kalan tüm bölgeler, bu anlaşma uyarınca idareleri geçici olarak devredilmiş olmasına bakılmaksızın, Kuruluş Antlaşması'nın yürürlüğe girişinden itibaren parçasını oluşturdukları kurucu devletin yasal bir parçası olacaktır (md. 1). Böylece bu madde ile geçici idare kavramına açılık getirildiği görülmüştür.

Toprak düzenlemeleriyle ilgili olarak güvenliğin sağlanması ve buna dair işbirliğin sağlanması gerektiği de belirtilmiştir. Buna göre safhalı dönem boyunca Kıbrıs Rum Devleti ve Kıbrıs Türk Devleti'nin idaresi altındaki bölgeler, geçici direklerle işaretleneceği ve bu dönem süresince, 10 geçiş noktasından daha az olmayacağı kararlaştırılmıştır (md. 4/1). Ancak toprak ayarlamaları boyunca, her iki kurucu devletten birer ve bu komitenin başkanı olacak BM'den bir temsilciyi içerecek bir Geçiş Komitesi oluşturulacağı da dikkatlerden kaçmamıştır. Özellikle bu komite; toprak düzenlemeleri veya bir komite üyesi tarafından dile getirilen, bir kurucu devletteki diğer kurucu devlet iç vatandaşlı̆̆ı statüsüne sahip kişilerin mevcudiyetine dair her konuyu değerlendirebilecektir. Ayrıca komite, kamu düzeni ve güvenliği nedeni ile üzerinde anlaşılan geçiş noktalarının ne zaman veya ne kadarlık bir süre içinde kapatılacağını ya da geçiş noktalarını kullanacak kişilerin sayısına getirilecek geçici sınırlamaların ne kadar olacağını da belirleyecektir (md. 4/2).

Bundan da anlaşılmaktadır ki, Geçici Güvenlik Düzenlemeleri, Annan Planı'nın önemli kriterlerinden biridir. Özellikle Kıbrıs'ta yeni devlet düzenine ilişkin olarak Kıbrıs, Yunanistan, Türkiye ve Birleşik Krallık arasındaki antlaşma gereğince 'Geçici Güvenlik Düzenlemeleri' yapılacağı ve bu düzenlemelere ilişkin olarak taraflarca belirlenen maddelerin onaylanacağı, üzerinde mutabakata varılacağı ve bu Antlaşma'yla birlikte imzalanarak, yürürlüğe gireceği kararlaştırılmıştır (md. 6). ${ }^{103}$

Akademik

İttifak Antlaşması'nın Ek Protokol IV.'de ise bu anlaşma uyarınca Yunan ve Türk birliklerinin sırasıyla Kıbrıs Rum Devleti ve Kıbrıs Türk Devleti'nde konuşlanmasına izin verileceğini (md. 3/1), İttifak Anlaşması'nın ilgili hükümlerine halel gelmeksizin, geçici bir süre için, Yunan ve Türk birliklerinin sayısı tüm rütbeler dahil 6.000'i, Türkiye'nin AB'ye katılım tarihine kadar ise tüm rütbeler dahil 3.000'i aşmayacak şekilde olacağı kayda alınmıştır (md. 3/2). Bu tarihten sonra Kıbrıs, Yunanistan ve Türkiye askerlerinin tümünün adadan çekilmesi amacıyla her beş yılda bir, ordu seviyeleri gözden geçirileceği ve bu durumun,

103 Bu hüküm “Kıbrıs'taki Yeni Devlet Düzenine İlişkin Kıbrıs, Yunanistan, Türkiye ve Birleşik Krallık Arasındaki Antlaşma"nın 6. maddesinde yer almaktadır. Bunun için bkz... "Kıbrıs Sorununun Kapsamlı Çözümü - 30 Mart 2004", KKTC CBA, Dosya: BM Önerileri - Annan Plânı, Tarih: 30 Mart 2004. 
hiçbir şekilde İttifak Anlaşması ve Ek Protokollerinin hükümlerine ve şimdiye kadar verilen hak ve sorumluluklara zarar vermeyeceği belirtilmiştir (md. 3/3). Buna karşın Türk ve Yunan birliklerinin oluşumu, teçhizatı, konuşlanma bölgeleri ve faaliyetleri, bu Protokolün ek hükümlerine uygun olarak yapılacağı ve donanım miktarları, belirtilen asker sayısındaki azalmaya uygun olarak azaltılacağı kararlaştırılmıştır (md. 3/4).

\section{Sonuç}

Kıbrıs, sahip olduğu yüzölçümü ve nüfusuyla orantılı olmayacak kadar büyük bir soruna sahiptir. Bunun başlıca sebebi, adanın ilgi çeken konumudur. Zira Kıbrıs, yüzyıllardan beri Doğu Akdeniz'e egemen olmak isteyen veya bu bölgede var olmakta yarar gören güçlerin ilgi odağı olmuştur.

Kıbrıs'ta çözüme yönelik siyasal ve hukuksal girişimlerin başarılı olmaması, sorunun giderek yoğunlaşan bir şekilde uluslararası hukuk ve politikanın ilgi alanına taşımıştır. Soruna, uluslararası hukuk ve politika açısından bakıldığında, bu sorunun temel dinamiklerinin kavranabilmesi için ilgili devletlerin ve uluslararası aktörlerin yaklaşımları ile dünya sistemindeki değişimlerin önemli ölçüde etkili olduğu görülmektedir. Dolayısıyla Kıbrıs, bugün itibarıyla ekonomiden siyasete, toplumsal ilişkilerden uluslararası imajına kadar hemen her alanda, ciddi bir 'sorunla' karşı karşıya bulunmaktadır.

Esasında Kıbrıs meselesi, çok yönlü bir meseledir. Bu çok yönlü ve bilinmeyenli denklemin 'çözümü’ için de politik bir tarih belirtmek gerekirse, bu tarih 1992 olarak belirtilebilir. Çünkü ilk kez Kıbrıs meselesinde kapsamlı ve bütüncül bir çözüm plânı hazırlanmış ve tarafların uzlaşması için önlerine nihaî belge olarak sunulmuştur. Ancak 1992'de Genel Sekreter Butros Gali'nin sunduğu Fikirler Dizisi ile Kofi Annan'ın 2002-2004'te sunduğu öneriler arasında birtakım önemli farklar olduğu ortadadır. Bu yüzden gerek Gali, gerekse Annan plânında güvenlik, iki bölgelilik, sınırlar, ortak devlete katılım, gayrimenkuller gibi kritik alanlarda benimsenen kavramlar ve ileri sürülen çözümler birbirlerinden kısmen farklıdır. Ancak Kofi Annan'ın önerilerini hazırlayanlar, Gali Fikirler Dizisi'nden geniş ölçüde ilham almışlardır. Buna rağmen her iki çözüm önerisine, gerek Kıbrıs Türk tarafının, gerekse Türkiye'nin tepkileri taban tabana zıt olduğu da müşahede edilmiştir. Fakat yine de Kofi Annan, hazırladığı belgenin güvenlik, garantiler, yerlerinden edilmiş kişiler, toprak ayarlamaları, federasyonun anayasal yönleri ve kapsamlı amaçlar başlıklı bölümlerinde kabul edilmesi güç unsurşarının da yer aldığı bir gerçektir. Ancak istenilmeyenler arasında geçici dönem ile ilgili düzenlemelerin ağırlığı oldukça azdır. Hatta denilebilir ki bu hükümler, kalıcı anlaşmanın bulunması yönünde önleyici bir nitelik taşımamaktadır. Sadece geçiş döneminin süreci konusunda Türk tarafının isteği, sürenin biraz daha uzun olmasıdır. Rumlar ise bu sürenin mümkün olduğu kadar kısa olmasını arzulamaktadırlar.

Akademik Bakış 215 Cilt 8 Sayı 15 Kış 2014 
Aslında bütün bunlardan göstermektedir ki, Kıbrıs'ta barış yapmak, savaş yapmaktan çok daha zordur. Bu yüzden Kıbrıs meselesi, taraftarının birbirine yüzde yüz zıtlıkta farklı görüşlere sahip olduğu ve kendi davalarının haklılığını kanıtlamak için aşırı derece çaba gösterdikleri konulardan birisi olarak ortaya çıkmaktadır.

Bu yüzden Kıbrıs meselesi tartışılırken ve bugünkü durumla ilgili fikirler ve çözümler ortaya atılırken, sorunun kökeni içinde bulunan 1974 öncesi dönemin de değerlendirilmesi gerekmektedir. Hâl böyle olunca meselenin hâlli için önerilecek çözümlerin, geçmişin gerçeklerine dayanması gerektiği ortadadır.

\section{Kaynaklar \\ 1. Arşiv Belgeleri:}

"10 Aralık 2002 Tarihli Kıbrıs Sorununun Kapsamlı Çözümü İçin Anlaşma Temeli - Annan Plan for Cyprus Settlement - Full Text 10 December 2002", KKTC Cumhuriyet Meclisi Arşivi, Dosya: Annan Planı, Tarih: 2002.

"1990 Yılında Sunulan 27 Sayfalık Türk Önerileri”, KKTC Cumhurbaşkanı Arşivi, Dosya: Türk Önerileri, Tarih: 1990.

"Birleşmiş Milletler Çözüm Plânının Tam Metnini Açıklıyoruz", KKTC Dışişleri ve Savunma Bakanlığı Arşivi, Konu: Gali Fikirler Dizisi, Tarih: 1992.

"BM Genel Sekreteri'nin Kıbrıs Özel Temsilcisi Weckman Aracılığı ile 18 Temmuz 1975'te Klerides'e Gönderdiği Mektup”, KKTC Cumhurbaşkanlı̆̆ı Arşivi, Dosya: Klerides'in Demeçleri, Tarih: 1975.

"Güvenlik Konseyi Gali Raporu'nu Ele Alıyor", KKTC Başbakanlık Enformasyon Müdürlüğü Arşivi, Dosya: Gali Fikirler Dizisi, Tarih: 10 Nisan 1992.

"Kıbrıs Rum Basını Özetleri”, Türk Ajansı Kıbrıs Arşivi, 22 Şubat 1995, s. 1.

"Kıbrıs Sorununun Kapsamlı Çözümü - 30 Mart 2004”, KKTC Cumhurbaşkanı Arşivi, Dosya: BM Önerileri - Annan Plânı, Tarih: 30 Mart 2004.

"Kıbrıs Türk Tarafının Bir Bütünün Parçasını Teşkil Eden Federal Yasama Organı ile İlgili Yaklaşım”, KKTC Cumhurbaşkanlığı Arşivi, Dosya: Türk Önerileri, Tarih: 30 Ocak 1989.

"Kıbrıs Türk Tarafının Entegre Bütünün Bir Parçası Olarak 'Kıbrıslı ve Kıbrıslı Olmayan Kuvvetler' Konusuna Yaklaşımı”, KKTC Cumhuriyet Meclisi Arşivi, Konu: Türk Önerileri, Tarih: 9 Ocak 1989.

"KKTC Cumhuriyet Meclisi Kararları", KKTC Cumhuriyet Meclisi Arşivi, Dosya: Karar Defteri, Tarih: 18 Mayıs 1993-1 12/3/1993 ve 18 Haziran 1993-117/3/1993 numaralı kararlar.

"Rum Basın Bülteni”, Türk Ajansı Kıbrıs Arşivi, 12 Kasım 1992, s. 3.

"Rum Basın Bülteni”, Türk Ajansı Kıbrıs Arşivi, 18 Eylül 1992, s. 1-2.

"Rum Basın Bülteni”, Türk Ajansı Kıbrıs Arşivi, 22 Temmuz 1992, s. 3. 
"Rum Basın Bülteni”, Türk Ajansı Kıbrıs Arşivi, 27 Ağustos 1992, s. 1.

"Rum Basın Özetleri”, KKTC Cumhurbaşkanlığı Arşivi, Dosya: Rum Basın Özetleri, Tarih: 7 Eylül 1992.

"Set of Ideas on an Overall Framework Agreement on Cyprus", KKTC Dışişleri ve Savunma Bakanlığı Arşivi, Konu: Gali Fikirler Dizisi, Tarih: 1992.

"Set of Ideas on an Overall Framework Agreement on Cyprus", KKTC Cumhurbaşkanlığı Arşivi, Konu: Gali Fikirler Dizisi, Tarih: 1992.

AKPINAR, Mehmet Ali (1992). "Birleşmiş Milletler Çözüm Plânının Tam Metnini Açıklıyoruz", KKTC Başbakanlık Enformasyon Müdürlüğü Arşivi, Konu: Gali Fikirler Dizisi, Tarih: 1992.

DELICEIRMAK, Orbay (1997). “Toprak Konusu ve Rum Tutarsızlıkları 19641996", KKTC Cumhurbaşkanlığı Arşivi - Yayınlanmamış Özel Rapor, Lefkoşa, 1997.

\section{Basılı Eserler:}

Background on The Cyprus Problem, Directorate General of Press and Information, Ünal Ofset Matbaacılık, Ankara, 1991.

Birleşmiş Milletler Güvenlik Konseyi'nin 789 (1992) Sayılı Kararının Işı̆ıında Kıbrıs Sorunu ve Türkiye, Siyasî ve Sosyal Araştırmaları Vakfı - SiSAV, İstanbul, 1993.

CERRAHOĞLU, Zehra Yalçınkaya. Birleşmiş Milletler Gözetiminde Kıbrıs Sorunu ile Illgili Olarak Yapılan Toplumlararası Görüşmeler (1968-1990), Kültür Bakanlığı Yayınları, İstanbul, 1998.

COTTERET, Jean Marie ve Claude EMERI. Seçim Sistemleri, (çev. Ahmet Kotil), Presses Universitaires de France, İletişim Yayınları, İstanbul, 1995.

DEDEÇAY, Servet Sami. Kıbrı'ta Enformasyon veya Yazılı ve Sözlü Basın, Cilt: 1., Lefkoşa Özel Türk Üniversitesi Yayınları: 5, Gelişim Ofset, Lefkoşa, 1988.

DELICEIRMAK, Orbay (der.), Hakllık ve Kararlilk (Tepkiler Demeti), Lefkoşa, 1993.

“Demokrasi”, Temel Britannica, 1994.

DENKTAŞ, Rauf Raif. Dünü Bugünü Yarını ile Kıbrıs Davamız, Lefkoşa, 1991.

Kıbrıs Meselesinde Son Durum, Raif Denktaş Eğitim Vakfı Yayınları No: 2, Lefkoşa, 1996.

DODD, Clemenet H. The Cyprus Issue-A Current Perspective, 2. Edition, The Eothen Press, England, 1995.

EFEGIL, Ertan. Temel Konular Işı̆ı̆ıda Annan Belgesi'nin Analizi, Gündoğan Yayınları, Ankara, 2003.

ERTEKÜN, Necati Münir. In Search of A Negotiated Cyprus Settlement, Nicosia, 1981. GAZiOĞLU, Ahmet. Ingiliz Yönetiminde Kıbrıs Son İki Yil (1958-1960) ENOSiS Çemberinden Kıbrıs Cumhuriyeti'ne-3, Kıbrıs Araştırma ve Yayın Merkezi Yayınları, Ankara, 2000. 
GÜREL, Şükrü S. Tarihsel Boyut Ľçinde Türk-Yunan İlişkileri (1821-1993), Ümit Yayıncilık, Ankara, 1993.

İSMAIL, Sabahattin. "Kıbrıs'ta Çözüm Önerileri ve Örnekleri”, Kıbrıs Üzerine Bildiriler, Kıbrıs Araştırma ve Yayın Merkezi (CYREP) Yayınları, Lefkoşa, 1998a, s. 178-223.

150 Sorunda Kıbrıs Sorunu, Kastaş Yayınları, İstanbul, 1998b.

Kıbrıs Sorunu Gelişmeler ve Görüşmeler, SiSAV Yayınları, Reyo Matbaacılık, İstanbul, 1990.

Kıbrıs Sorunu, Türkiye Barolar Birliği Yayınları, Sevinç Matbaaları, Ankara, 1975. NECATIGIL, Zaim M. The Cyprus Question and The Turkish Position in International Law, Revised 2. Edition, Biddles Ltd Guildford and King's Lynn, Oxford University Press, London, 1998.

SOYSAL, Mümtaz. Aklını Kıbrıs'la Bozmak, Bilge Yayınevi, İstanbul, 1995.

TAMÇELIK, Soyalp. “Birleşmiş Milletler Güvenlik Konseyi'nin Kıbrıs'la İlgili 789 Sayılı Kararı ve Buna Bağlı Toprak Hukuku”, Proceeding of The Third International Congress For Cyprus Studies (III. Uluslararası Kibrıs Araştırmaları Kongresi), Vol. III, Cyprus Issue and Tourism, Eastern Mediterranean University Center for Cyprus Studies Publications: 15, Mağusa, 2000, s. 391-418.

"Kıbrıs Meselesinde Metodolojik Sorunlar ve Çözüm Önerileri”, Journal of World of Turks, II/2, (2010a), s. 101-135.

"Kıbrıs'ta Askersizleştirme Faaliyetleri ve Saldırmazlık Doktrinin Esasları", Uluslararası Sosyal Araştırmalar Dergisi, IV/17, (2011a), s. 348-377.

"Kıbrıs'ta Gobi ve Gali Plânlarına Göre Harita Meselesi”, Uluslararası Insan Bilimleri Dergisi, IX/2, (2012a), s. 1031-1074.

"Kıbrıs'ta İç Göç Hareketleri ve Olası Bir Anlaşmada Etkileri”, Bilig Dergisi, 63, (2012b), s. 227-252.

“Kıbrıs'ta Kurulması Düşünülen Federal Devletin Yasama Organı ve Özellikleri", Yakın Doğu Üniversitesi Sosyal Bilimler Dergisi, II/1, (2009a), s. 20-50.

"Kıbrıs'ta Kurulması Düşünülen Federal Devlette Yargı Organları ve Temel Özellikleri", Türkiye Günlüğü Dergisi, 96, (2009b), s. 197-223.

"Kıbrıs'ta Kurulması Düşünülen Federal Sistemde Toplum (Cemaat) Meclisleri ve Özellikleri", Doğuş Üniversitesi Dergisi, XI/2, (2010b), s. 269-285.

"Kıbrıs'ta Kurulması Düşünülen Federasyonun Yapısal Özellikleri”, Uluslararası Tarih ve Sosyal Araştırmalar Dergisi, I/2, (2009c), s. 211-223.

“Kıbrıs'ta Kurulması Düşünülen Sistemde Cumhurbaşkanı ve Yardımcısının Görev ve Yetkileri", Akademik Araşttrmalar Dergisi, XI/42, (2009d), s. 76-96.

"Kıbrıs'ta Olası Bir Federal Hükümetin Görev ve Yetkileri”, Uluslararası Hukuk ve Politika Dergisi, V/17, (2009e), s. 55-84.

“Kıbrıs'ta Toprak Düzenlemeleri ve Temel Kriterleri”, Türk Kültürü Araştırmaları M. Cihat Özönder Armağanı, TKAE Yayınları, Ankara, 2012c, s. 265-307. 
“Kıbrıs'ta Toprak Müzakereleri ve Tarafların Çözüm Kriterleri (1974-1990)", Uluslararası Sosyal Araştırmalar Dergisi, V/23, (2012d), s. 377-396.

"Kıbrıs'taki İngiliz Üslerinin Stratejik Önemi”, Uluslararası İnsan Bilimleri Dergisi, VIII/1, (2011C), s. 1510-1539.

"Kıbrıslı Rumların Bölge Barışını Tehdit Eden Silahlanma Çabaları", Turkish Studies International Periodical for the Languages, Literature and History of Turkish or Turkic, VI/3, (2011d), s. 391-424.

"Rum-Yunan İttifakında Ortak Savunma Doktrini ve Özellikleri”, Stratejik Araştırmalar Dergisi, VI/12, (2008a), s. 13-39.

Kıbrıs Meselesinin Çözüm Plânları (BM'nin 789 Sayılı Kararına Göre), Gazi Üniversitesi Sosyal Bilimler Enstitüsü Yayımlanmamış Doktora Tezi, Ankara, 2008b.

Kıbrıs'taki Çatısmanın Hukukî Boyutu, IQ Yayınları, İstanbul, 2012e.

“TBMM'nin 10 Haziran 1993 Tarihinde "Kıbrıs Sorunu” ile İlgili Olarak Oy Birliğiyle Onayladığı Tarihi Bildiri”, Tutanak Dergisi, 10 Haziran 1993.

\section{Gazeteler:}

ALKAN, Hüseyin. “iş̧te Annan'ın Çözüm Plânı”, Hürriyet Gazetesi, 10 Kasım 2000, No:98562, s. 26.

“Planda Taraflar Neyi İstemiyor”, Hürriyet Gazetesi, 8 Aralık 2002, No:523361, s. 14. “Amerikalıların Plânı", Fileleftheros Gazetesi, 22 Şubat 1995, No:4407, s. 1.

BATUR, Nur. "Sırbistan - Karadağ Modeli Nedir?", Hürriyet Gazetesi, 13 Nisan 2003, No: 102336, s. 7.

"Belge Sunduk", Kibrıs Gazetesi, 12 Eylül 2002, No:6201, s. 1 ve 18.

“BM ve ABD Türklere Yüzde 29.5 Toprak Önerecek”, Simerini Gazetesi, 17 Temmuz 1992, No:3251, s. 21.

DELICEIRMAK, Cumhur. "Sinsilik", Birlik Gazetesi, 3 Ocak 1992, No:526, s. 11.

“DiSI: Boşluklar Doldurulmalı", Agon Gazetesi, 18 Eylül 1992, No:987, s. 1-2.

"Egemenliğe Dayanmayan Eşitlik, Eşitlik Değildir; Egemenliğe Dayanmayan Hak, Hak Değildir", Yeni Demokrat Gazetesi, 11 Ocak 1998, No:203, s. 7.

EKŞi, Oktay. "Kıbrıs'ta Son Tango", Hürriyet Gazetesi, 26 Ocak 2003, No:302564, S. 23.

ERGiN, Sedat. "70 Bin Rum, Türk Bölgesine Geçebilir-3”, Hürriyet Gazetesi, 21 Kasim 2002, No:122354, s. 18.

"Güvenlik Konseyi Gali Raporu'nu Ele Alıyor", Kıbrıs Gazetesi, 10 Nisan 1992, No:652, s. 8.

"Güvenlik Konseyi", Simerini Gazetesi, 27 Ağustos 1992, No:2018, s. 1.

“İşte Belge”, Kibris Gazetesi, 13 Kasım 2002, No:1028, s. 9 ve 16.

Akademik Bakış 219 Cilt 8 Sayı 15 Kış 2014 
“KKTC Meclisi'nin Son Kararı”, Kıbrıs Gazetesi, 2 Ağustos 1992, No:3819, s. 3.

"Referanduma Firsat Verilmeyecek”, Agon Gazetesi, 7 Eylül 1992, No:3002, s. 4. ULUÇ, Doğan. "New York'ta Harita Pazarlığı", Hürriyet Gazetesi, 21 Haziran 1992, No:75524, s. 12.

ÜLMAN, Haluk. "Her Çözüm, Çözüm Değildir", Yeni Günaydın Gazetesi, 24 Aralık 1992, No:5332, s. 14.

"Vasiliu'nun Demeci", Haravgi Gazetesi, 12 Kasım 1992, No:5211, s. 2-3.

"Yeni Gali Plânı", Alithia Gazetesi, 22 Temmuz 1992, No:1202, s. 3.

"Yorgo Vasiliu: İyi Bir Başlangıç", Hürriyet Gazetesi, 10 Aralık 1992, No:62235, s. 17. 